Article

\title{
Physiological and Transcriptomic Response of Grey Poplar (Populus Xcanescens Aiton Sm.) to Cadmium Stress
}

\author{
Martina Komárková ${ }^{1, * \mathbb{D}}$, Jakub Chromý ${ }^{1}$, Eva Pokorná ${ }^{1} \mathbb{D}$, Petr Soudek $^{2}$ (D) \\ and Pavlína Máchová 1 \\ 1 Forestry and Game Management Research Institute, Strnady, 25202 Jiloviste, Czech Republic; \\ chromy@vulhm.cz (J.C.); pokorna@vulhm.cz (E.P.); machova@vulhm.cz (P.M.) \\ 2 The Czech Academy of Sciences, Institute of Experimental Botany, 16502 Prague, Czech Republic; \\ soudek@ueb.cas.cz \\ * Correspondence: komarkova@vulhm.cz; Tel.: +420-257-892-263
}

Received: 17 September 2020; Accepted: 30 October 2020; Published: 4 November 2020

\begin{abstract}
Background: Populus $\times$ canescens (Aiton) Sm. is a fast-growing woody plant belonging to the family Salicaceae. Two poplar genotypes characterized by unique phenotypic traits (TP11 and TP20) were chosen to be characterized and tested for a physiological and transcriptomic response to Cd stress. (2) Methods: A comparative analysis of the effects of exposure to high cadmium (Cd) concentrations $(10 \mu \mathrm{M}$ and $100 \mu \mathrm{M})$ of TP11 and TP20 was performed. (3) Results: Neither of the tested $\mathrm{Cd}$ concentration negatively affected plant growth; however, the chlorophyll content significantly decreased. The potassium (K) content was higher in the shoots than in the roots. The magnesium concentrations were only slightly affected by Cd treatment. The zinc content in the shoots of TP20 was lower than that in the shoots of TP11. Cd accumulation was higher in the roots than in the shoots. After 10 days of exposure, $10 \mu \mathrm{M} \mathrm{Cd}$ resulted in comparable amounts of $\mathrm{Cd}$ in the roots and shoots of TP20. The most significant change in transcript amount was observed in endochitinase 2, 12-oxophytodienoate reductase 1 and phi classglutathione S-transferase. (4) Conclusions: Our study provided new insights for effective assessing the ability of different poplar genotypes to tolerate $\mathrm{Cd}$ stress and underlying $\mathrm{Cd}$ tolerance.
\end{abstract}

Keywords: cadmium; gene expression; grey poplar; microsatellite analysis; mineral uptake; translocation factor

\section{Introduction}

Environment plays a crucial role in ensuring global health. Different sources of environmental stress lead to severe problems in many parts of the world, including social and economic impacts. In recent years, soil heavy metal pollution has attracted global attention. Heavy metals tend to accumulate in living organisms and cause serious deleterious effects. In soil, cadmium $(\mathrm{Cd})$ originates mostly as an emission from industrial processes. Due to its low adsorption coefficient and high soil-plant mobility, $\mathrm{Cd}$ may enter the food chain. Plant $\mathrm{Cd}$ uptake occurs mainly via roots and is taken up into the cell by passive and active pathways, mediated by carriers and channels permeable to essential nutrients [1-3]. Within plants, $\mathrm{Cd}$ causes phytotoxicity by inhibiting plant growth and respiration [4], causing the dysfunction of photosynthesis and stomatal closure [5], disrupting ATPase activity [6] or decreasing water and nutrient uptake and transport [7]. At the cellular level, high Cd concentrations can cause the overproduction of reactive oxygen species (ROS), protein oxidation, membrane lipid peroxidation [8], chromosomal aberration and DNA or RNA damage [9]. In addition, 
transcriptomic changes in several kinds of genes upon Cd stress have been investigated in several plant species $[10,11]$.

The ability of plants to uptake and store heavy metals from soil into their parts can be used as an alternative technology called phytoremediation. Phytoremediation is a very promising method for the detection and removal of toxic metals accumulated in the environment [12]. This technique uses the ability of some plant species to remove contaminants by absorbing them into the aboveground plant parts. To date, many hundreds of different plant species that specialize in the hyperaccumulation of a particular contaminant have been described [13]. The most studied hyperaccumulator is probably Thlaspi caerulescens J.Presl \& C.Presl, with a marked ability to accumulate zinc ( $\mathrm{Zn})$ and $\mathrm{Cd}$ into its aboveground tissues [14-16]. Other identified hyperaccumulators have also been described, for example, Alyssum species with nickel (Ni) phytoextraction potential [17], the arsenic (As) hyperaccumulator fern Pteris vittata L. [18], and Arabidopsis halleri L. with $\mathrm{Zn}$ and slight Cd hyperaccumulation capacities [19]. Unfortunately, the limited biomass of herbaceous plants prevents their application for phytoremediation on a large scale. Woody plants, including some poplar genotypes, have been proposed for phytoremediation due to their rapid growth, deep root system and high Cd accumulation capacity [20].

The diploid genus Populus (poplar) is known to have high amounts of intraspecific variability and widespread hybridization between ecologically differentiated species [21]. Populus $\times$ canescens Aiton Sm. (grey poplar) is a product of ongoing gene flow between its parents, Populus alba L. and Populus tremula L. [22]. For grey poplar, both sexual and clonal reproduction are common [23]. Thus, genetic analyses (simple sequence repeat (SSR)) can be used to differentiate between asexual and sexual propagation and between different clones [24,25]. Simple sequence repeats are tandem repeats of DNA sequences 1-6 base pairs (bp) in length and represent powerful tools in screening plant genomic DNA usable in taxonomy, genetic mapping, population genetics and genotoxicity tests [26-28].

To elucidate $\mathrm{Cd}$ distribution and physiological responses to heavy metal stress in fast-growing woody plant species, two poplar (P. canescens) genotypes with unique phenotypic traits were exposed to 0,10 or $100 \mu \mathrm{M} \mathrm{CdCl}_{2}$. The objective of this experiment was to address the following concepts: (1) the effect of $\mathrm{Cd}$ on the growth and mineral uptake in genotypes TP11 and TP20; (2) whether the selected poplar genotypes exhibited phytoextraction potential towards $\mathrm{Cd}$; and (3) whether $\mathrm{Cd}$ exposure causes changes in the gene expression level. The obtained results may not only help us to better understand the physiological and transcriptomic regulation mechanisms of woody plants towards $\mathrm{Cd}$ exposure but also provide guidelines for the selection of genotypes with high $\mathrm{Cd}$ tolerance and phytoremediation potential.

\section{Results and Discussion}

\subsection{Microsatellite Analysis}

Since poplar trees are known to produce root sprouts and thus generate clones of one individual [29], it was necessary to distinguish the genotypes of selected trees. Signs of differentiation are well detectable by genetic analyses with molecular markers, such as nuclear SSRs. To determine whether the selected poplar plants shared the same genotype, they were screened for variation at 15 nuclear SSR loci. The tested SSRs, except ORPM14, were sufficiently polymorphic to be used for the genetic structure analyses of grey poplar. A summary of the allele size of the SSRs analysed in source plants is presented in Table 1. The simple sequence repeats WPMS5, WPMS20, ORPM14, ORPM16, ORPM127 and ORPM312 presented homozygous individuals with one allele each in TP11. In the second poplar genotype, 8 homozygous alleles were observed in SSRs WPMS19, WPMS20, ORPM14, ORPM16, ORPM60, ORPM127, ORPM220 and ORPM312. The same allele sizes in both genotypes were obtained only by 8 SSRs (Table 1). These results of our genetic analysis show that the microsatellite regions of the two selected poplar trees were different. 
Table 1. Summary of the allele sizes obtained from the SSR analysis.

\begin{tabular}{ccc}
\hline SSR & \multicolumn{2}{c}{ Allele Size } \\
\hline & TP11 & TP20 \\
WPMS5 & 298 & $276 / 310$ \\
WPMS15 & $189 / 192$ & $189 / 192$ \\
WPMS16 & $165 / 171$ & $165 / 171$ \\
WPMS18 & $222 / 228$ & $219 / 222$ \\
WPMS19 & $195 / 204$ & 186 \\
WPMS20 & 178 & 178 \\
ORPM14 & 141 & 141 \\
ORPM16 & 223 & 223 \\
ORPM20 & $180 / 196$ & $197 / 201$ \\
ORPM30 & $221 / 229$ & $207 / 219$ \\
ORPM60 & $200 / 206$ & 206 \\
ORPM127 & 189 & 189 \\
ORPM193 & $175 / 190$ & $175 / 190$ \\
ORPM220 & $217 / 229$ & 217 \\
ORPM312 & 195 & 195 \\
\hline
\end{tabular}

\subsection{Effect of $\mathrm{Cd}$ on Plant Growth and Chlorophyll Content}

Populus canescens plantlets were exposed to two Cd concentrations (10 $\mu \mathrm{M}$ and $100 \mu \mathrm{M})$ that did not abolish growth. The responses of poplar clones TP11 and TP20 to Cd were first screened by visual observation. Cadmium toxicity is often accompanied by characteristic leaf symptoms, including chlorosis and necrosis [30-32]. After the addition of $100 \mu \mathrm{M} \mathrm{Cd}$, only slight leaf chlorosis was observed, while other plants (control and $10 \mu \mathrm{M}$ treatment) did not show any significant symptoms of toxicity (data not shown).

The effects of $\mathrm{Cd}$ treatments on the growth parameters and chlorophyll content of $P$. canescens are shown in Table 2. Neither tested Cd concentration negatively affected root length at either time point ( 2 and 10 days after $\mathrm{Cd}$ exposure). Interestingly, longer roots were measured for both grey poplar genotypes after 2 and also 10 days of $10 \mu \mathrm{M}$ and $100 \mu \mathrm{M} C d$ treatments compared to the controls (Table 2). Relatively similar root weights were detected for TP11 (75.0 \pm 3.6 and $85.3 \pm 4.2 \mathrm{mg})$ and TP20 (71.3 \pm 5.5 and $84.3 \pm 5.5 \mathrm{mg})$ at 2 days after $10 \mu \mathrm{M}$ and $100 \mu \mathrm{M} \mathrm{Cd}$ application in comparison to the significantly different shoot weights after 2 days of $10 \mu \mathrm{M}$ and $100 \mu \mathrm{M} \mathrm{Cd}$ treatment, reaching $255.7 \pm 49 \mathrm{mg}$ and $226.0 \pm 56 \mathrm{mg}$ in TP11 and $157 \pm 39 \mathrm{mg}$ and $151.0 \pm 45 \mathrm{mg}$ TP20, respectively. We found that prolonged treatment with both $\mathrm{Cd}$ concentrations resulted in an increase in biomass, especially in root length and root weight. Previous studies have shown that $\mathrm{Cd}$ addition leads to the dramatic inhibition of root growth, probably due to the influence of the homeostasis of auxin and ROS [33]. On the other hand, Schützendübel et al. [34] showed that $5 \mu \mathrm{M} \mathrm{Cd}$ stimulated root growth in hydroponically grown grey poplar, which correlates with our findings. A concentration of $50 \mu \mathrm{M} \mathrm{Cd}$ resulted in growth inhibition within $48 \mathrm{~h}$ [34]. In our experiment, root growth was not affected for either genotype when treated with $100 \mu \mathrm{M} \mathrm{Cd}$.

In general, the contents of chlorophyll $a$ and $a+b$ declined in both poplar genotypes with prolonged Cd treatment (both $10 \mu \mathrm{M}$ and $100 \mu \mathrm{M} \mathrm{Cd}$ ) compared to the control conditions (Table 2). In TP 11 and TP20, the chlorophyll $b$ content was not significantly different between the control and $\mathrm{Cd}$ treatments. Similarly, in TP20, the chlorophyll $b$ content was not significantly different between the control and $\mathrm{Cd}$ treatments. Cadmium is known to be responsible for chloroplast damage and interfering with chlorophyll biosynthesis, causing an inverse correlation between the chlorophyll content and Cd concentration [35,36]. 
Table 2. Root length (cm), root weight (mg), shoot weight $(\mathrm{mg})$ and chlorophyll content $\left(\mathrm{mg} \mathrm{g}^{-1} \mathrm{FW}\right)$ in two different cultivars of grey poplar (Populus $\times$ canescens Aiton Sm.) plants after 2 and 10 days of growth in the presence of different concentrations of $C d$. Data are presented as the mean $\pm \operatorname{SD}(n=3)$. Values followed by the same letter(s) within the same column are not significantly different according to Tukey's test $(p<0.05)$.

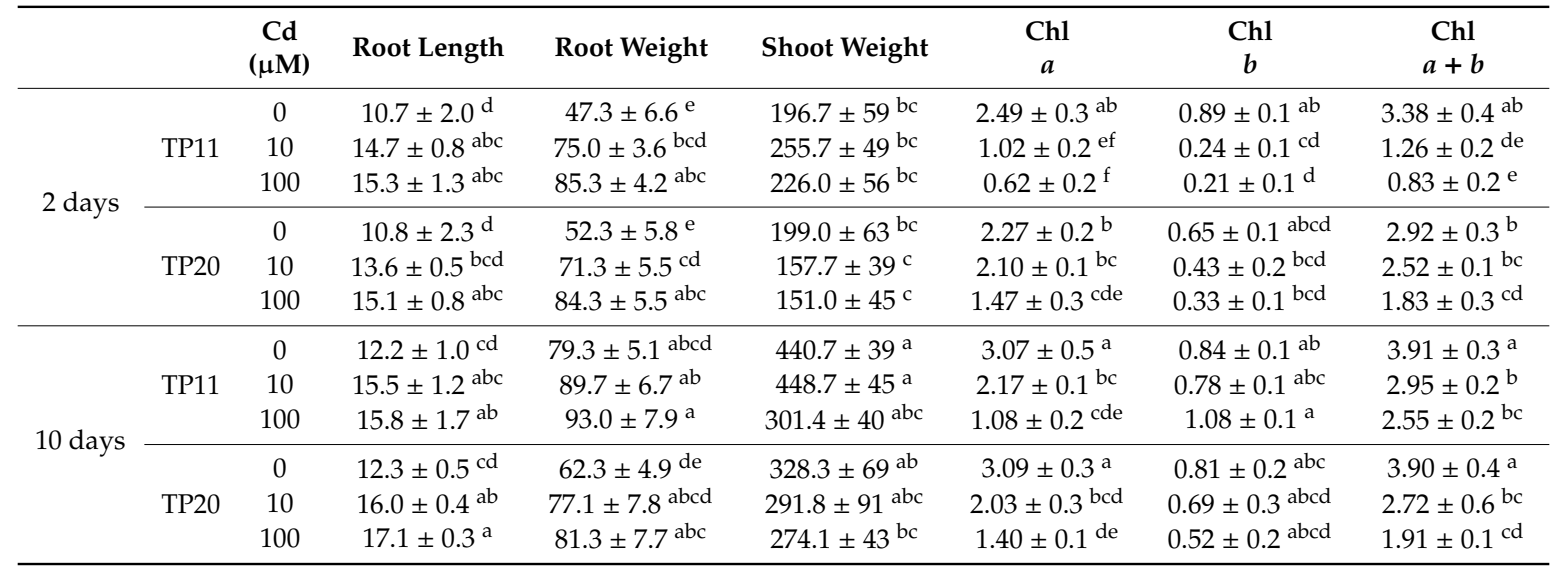

\subsection{Effect of $\mathrm{Cd}$ on $\mathrm{K}, \mathrm{Ca}, \mathrm{Mg}$ and $\mathrm{Zn}$ Uptake and Translocation}

Table 3 shows the mineral content in the roots and shoots of the two selected genotypes of P. canescens. The potassium (K) contents were significantly lower in the roots than in the shoots in both genotypes at all tested concentrations of $\mathrm{Cd}$. The root $\mathrm{K}$ content in the TP11 genotype significantly increased only after 10 days of $100 \mu \mathrm{M} \mathrm{Cd}$ treatment $\left(20.35 \mathrm{~g} \mathrm{~kg}^{-1}\right)$ compared to the control conditions $\left(11.70 \mathrm{~g} \mathrm{~kg}^{-1}\right)$. In the shoots, TP11 exhibited a reduction in the $\mathrm{K}$ content $\left(23.57 ; 24.29 \mathrm{~g} \mathrm{~kg}^{-1}\right)$ after 2 days under both $\mathrm{Cd}$ treatments compared to the control $\left(30.19 \mathrm{~g} \mathrm{~kg}^{-1}\right)$ conditions. In contrast, enhanced levels of the K content in the shoots were observed in TP20 after 10 days of Cd exposure. Potassium is one of the most important plant nutrients with high mobility and significant effects on different metabolic processes [37]. $\mathrm{K}$ application enhanced $\mathrm{Cd}$ tolerance in bean plants [38]. In our experiment, an increase in $\mathrm{K}$ was observed mainly in the roots, which is consistent with the results from Trifolium repens L. [39] or Triticum aestivum L. [40].

Calcium (Ca) and $\mathrm{Cd}$ compete for $\mathrm{Ca}^{2+}$ channels and intracellular Ca-binding proteins, thus influencing their contents [41]. In our experiment, Ca accumulation values were higher in the shoots than in the roots of all tested TP11 and TP20 plants. However, the Ca concentrations in the roots and shoots were, in most cases, not significantly changed after $\mathrm{Cd}$ exposure in either of the tested genotypes. Only in TP11 shoots after treatment with $100 \mu \mathrm{M} \mathrm{Cd}$ for 2 days was a significant increase in $\mathrm{Ca}\left(8.54 \mathrm{~g} \mathrm{~kg}^{-1}\right)$ detected compared to the control condition $\left(6.60 \mathrm{~g} \mathrm{~kg}^{-1}\right)$.

Magnesium $(\mathrm{Mg})$ and Ca exhibit the same inhibitory effect due to the competition of these divalent cations. In our study, $\mathrm{Mg}$ concentrations were slightly reduced in the roots of both genotypes after 10 days of $10 \mu \mathrm{M} \mathrm{Cd}$ treatment. On the other hand, TP20 accumulated higher amounts of $\mathrm{Mg}$ in roots exposed to $100 \mu \mathrm{M} \mathrm{Cd}$ for 2 days. Regarding the shoot Mg content, a slight change was observed only in TP11, with an enhanced Mg content after 10 days of $100 \mu \mathrm{M} \mathrm{Cd}$ treatment $\left(2.64 \mathrm{~g} \mathrm{~kg}^{-1}\right)$ compared to control conditions $\left(1.73 \mathrm{~g} \mathrm{~kg}^{-1}\right)$.

Zinc (Zn) concentrations were quite homogenous among the plant parts. The only difference was that both clones exhibited slightly higher amounts of $\mathrm{Zn}$ in the shoots after 10 days of $\mathrm{Cd}$ treatment compared to control conditions. The Zn content was lower in TP20 shoots than in TP11 shoots both in the 2- and 10-day controls and Cd-treated plants. According to Tkalec et al. [42], Cd exhibits a negative effect on $\mathrm{Zn}$ uptake in the leaves and roots. Cd can be taken up by the same transporters that are involved in $\mathrm{Zn}$ uptake and transport [43,44]. 
Table 3. Contents of $\mathrm{K}, \mathrm{Ca}, \mathrm{Mg}$, and $\mathrm{Zn}\left(\mathrm{g} \mathrm{kg}^{-1} \mathrm{DW}\right.$ ) in the roots and shoots of Populus $\times$ canescens (Aiton Sm.) genotypes TP11 and TP20 grown in perlite for 2 or 10 days with or without $\mathrm{Cd}(0 \mu \mathrm{M}, 10 \mu \mathrm{M}$ and $100 \mu \mathrm{M})$. Data are presented as the mean $\pm \mathrm{SD}(\mathrm{n}=3)$. Values followed by the same letter(s) within the same column are not significantly different according to Tukey's test $(p<0.05)$.

\begin{tabular}{|c|c|c|c|c|c|c|c|c|c|c|}
\hline & & & \multicolumn{2}{|c|}{$\mathrm{K}$ Content $\left(\mathrm{g} \mathrm{kg}^{-1}\right)$} & \multicolumn{2}{|c|}{ Ca Content $\left(\mathrm{g} \mathrm{kg}^{-1}\right)$} & \multicolumn{2}{|c|}{ Mg Content $\left(\mathrm{g} \mathrm{kg}^{-1}\right)$} & \multicolumn{2}{|c|}{ Zn Content $\left(\mathrm{g} \mathrm{kg}^{-1}\right)$} \\
\hline & & & Roots & Shoots & Roots & Shoots & Roots & Shoots & Roots & Shoots \\
\hline \multirow{6}{*}{2 days } & \multirow{3}{*}{ TP11 } & Cont & $13.24 \pm 1.93$ hij & $30.19 \pm 1.84^{\mathrm{a}}$ & $5.05 \pm 0.21^{\mathrm{fgh}}$ & $6.60 \pm 1.11 \mathrm{cde}$ & $1.64 \pm 0.15^{b c d}$ & $1.50 \pm 0.11^{\mathrm{cd}}$ & $0.22 \pm 0.05 \mathrm{ab}$ & $0.16 \pm 0.06^{\text {abcdef }}$ \\
\hline & & $\mathrm{Cd} 10$ & $10.40 \pm 0.87^{j}$ & $23.57 \pm 2.75$ bcde & $4.04 \pm 0.31^{\mathrm{h}}$ & $5.93 \pm 0.70$ def & $1.42 \pm 0.26^{\mathrm{cd}}$ & $1.64 \pm 0.18^{\mathrm{bcd}}$ & $0.20 \pm 0.04 \mathrm{abc}$ & $0.17 \pm 0.01$ abcde \\
\hline & & Cd100 & $12.50 \pm 1.19$ hij & $24.29 \pm 2.58$ bcde & $4.69 \pm 0.36^{\text {fgh }}$ & $8.54 \pm 0.44^{\mathrm{ab}}$ & $2.02 \pm 0.43$ abcd & $2.41 \pm 0.52 \mathrm{abc}$ & $0.25 \pm 0.04^{\mathrm{a}}$ & $0.17 \pm 0.03^{\mathrm{abcd}}$ \\
\hline & \multirow{3}{*}{ TP20 } & Cont & $12.22 \pm 2.68^{\text {hij }}$ & $21.24 \pm 1.60^{\text {cdef }}$ & $5.03 \pm 0.91 \mathrm{gh}$ & $7.07 \pm 0.42^{\mathrm{abcd}}$ & $1.53 \pm 0.51 \mathrm{bcd}$ & $1.85 \pm 0.99 \mathrm{abcd}$ & $0.14 \pm 0.02$ bcdef & $0.08 \pm 0.00^{\mathrm{f}}$ \\
\hline & & $\mathrm{Cd} 10$ & $16.03 \pm 3.12^{\mathrm{fgh}}$ & $22.81 \pm 2.02^{b c d e f}$ & $4.39 \pm 0.58 \mathrm{gh}$ & $6.86 \pm 0.38 \mathrm{bcd}$ & $2.22 \pm 0.11 \mathrm{abcd}$ & $1.95 \pm 0.18^{\mathrm{abcd}}$ & $0.17 \pm 0.07$ abcdef & $0.08 \pm 0.03^{\text {ef }}$ \\
\hline & & Cd100 & $16.25 \pm 0.38$ ghi & $25.60 \pm 1.52^{\mathrm{abcd}}$ & $4.75 \pm 1.04 \mathrm{gh}$ & $6.68 \pm 0.84^{\mathrm{abcd}}$ & $2.83 \pm 0.20^{\mathrm{a}}$ & $1.94 \pm 0.01 \mathrm{abcd}$ & $0.18 \pm 0.02^{\mathrm{abcd}}$ & $0.09 \pm 0.03$ def \\
\hline \multirow{6}{*}{10 days } & \multirow{3}{*}{ TP11 } & Cont & $11.70 \pm 0.98^{\mathrm{ij}}$ & $27.43 \pm 2.47^{a b c}$ & $5.04 \pm 1.03 \mathrm{gh}$ & $6.64 \pm 0.61$ abcd & $1.67 \pm 0.00^{\mathrm{bcd}}$ & $1.73 \pm 0.51^{\mathrm{abcd}}$ & $0.21 \pm 0.03^{a b c}$ & $0.14 \pm 0.01^{\text {bcdef }}$ \\
\hline & & $\mathrm{Cd} 10$ & $14.76 \pm 2.31$ hij & $27.36 \pm 1.73^{\mathrm{abc}}$ & $3.78 \pm 0.31^{\mathrm{h}}$ & $5.49 \pm 0.96^{\text {defg }}$ & $1.13 \pm 0.22^{\mathrm{d}}$ & $1.83 \pm 0.45^{\mathrm{abcd}}$ & $0.14 \pm 0.01$ bcdef & $0.21 \pm 0.04 \mathrm{abc}$ \\
\hline & & Cd100 & $20.35 \pm 1.33^{\text {defg }}$ & $26.88 \pm 2.84^{\mathrm{ab}}$ & $4.41 \pm 0.72 \mathrm{gh}$ & $8.13 \pm 0.81^{\mathrm{a}}$ & $2.02 \pm 0.044^{\mathrm{abcd}}$ & $2.64 \pm 0.77^{\mathrm{ab}}$ & $0.16 \pm 0.03 \mathrm{bcdef}$ & $0.22 \pm 0.03^{\mathrm{ab}}$ \\
\hline & \multirow{3}{*}{ ТР20 } & Cont & $9.96 \pm 1.54^{j}$ & $19.40 \pm 0.59$ defg & $4.66 \pm 0.63^{\mathrm{fgh}}$ & $6.45 \pm 1.06^{\mathrm{cd}}$ & $2.14 \pm 0.12^{\mathrm{abcd}}$ & $1.64 \pm 0.25^{b c d}$ & $0.18 \pm 0.04^{\mathrm{abcd}}$ & $0.08 \pm 0.00^{f}$ \\
\hline & & $\mathrm{Cd} 10$ & $15.26 \pm 2.72$ hij & $26.46 \pm 2.00 \mathrm{abcd}$ & $3.70 \pm 5.60^{\mathrm{h}}$ & $6.30 \pm 1.04^{\mathrm{cd}}$ & $1.13 \pm 0.12^{\mathrm{d}}$ & $1.73 \pm 0.31 \mathrm{abcd}$ & $0.20 \pm 0.02 \mathrm{abc}$ & $0.13 \pm 0.03$ bcdef \\
\hline & & Cd100 & $14.00 \pm 3.49$ hij & $26.81 \pm 2.10^{\mathrm{ab}}$ & $5.00 \pm 0.51 \mathrm{fgh}$ & $7.98 \pm 0.51 \mathrm{abc}$ & $1.93 \pm 0.13 \mathrm{abcd}$ & $2.10 \pm 0.18$ abcd & $0.13 \pm 0.03^{\text {cdef }}$ & $0.15 \pm 0.03$ bcdef \\
\hline
\end{tabular}




\subsection{Cadmium Accumulation, Translocation and TF}

To evaluate the ability of poplar to uptake $\mathrm{Cd}$ and accumulate it within the plant, the $\mathrm{Cd}$ content was analysed in the roots and shoots of the two selected grey poplar genotypes (TP11 and TP20). The translocation of $\mathrm{Cd}$ from the roots to the shoots was estimated by translocation factor (TF), which is defined as the ratio of the metal concentration in the shoot tissues to that in the root tissues. The concentration of $\mathrm{Cd}$ and $\mathrm{Cd}$ uptake was slightly different in the two tested P. canescens genotypes (Figure 1). With one exception (TP20, 10 days at $10 \mu \mathrm{M} \mathrm{Cd}$ incubation, Figure 1d), all plants accumulated more $\mathrm{Cd}$ in the roots than in the shoots. After 2 days of $100 \mu \mathrm{M} C \mathrm{~d}$ treatment, genotype TP11 accumulated significantly more $\mathrm{Cd}$ in the roots than genotype TP20 (Figure 1). In addition, the TF for genotype TP20 was higher in both Cd treatments $(10 \mu \mathrm{M}$ and $100 \mu \mathrm{M})$ and in both tested days compared to that for genotype TP11 (Table 4).

After 10 days of $10 \mu \mathrm{M}$ Cd exposure, genotype TP20 accumulated comparable amounts of Cd in the roots (58.65 mg Cd kg-1) and in the shoots (59.62 $\mathrm{mg} \mathrm{Cd} \mathrm{kg}^{-1}$ ), which was reflected by a TF value greater than 1 . The obtained results suggest variability among the grey poplar genotypes in $\mathrm{Cd}$ accumulation and translocation. Our data revealed that genotype TP20 may be a good candidate for Cd phytoextraction processes, similar to other tolerant poplar species, such as P. alba [45], Populus deltoides Marshall [46] or Populus nigra L. [47].
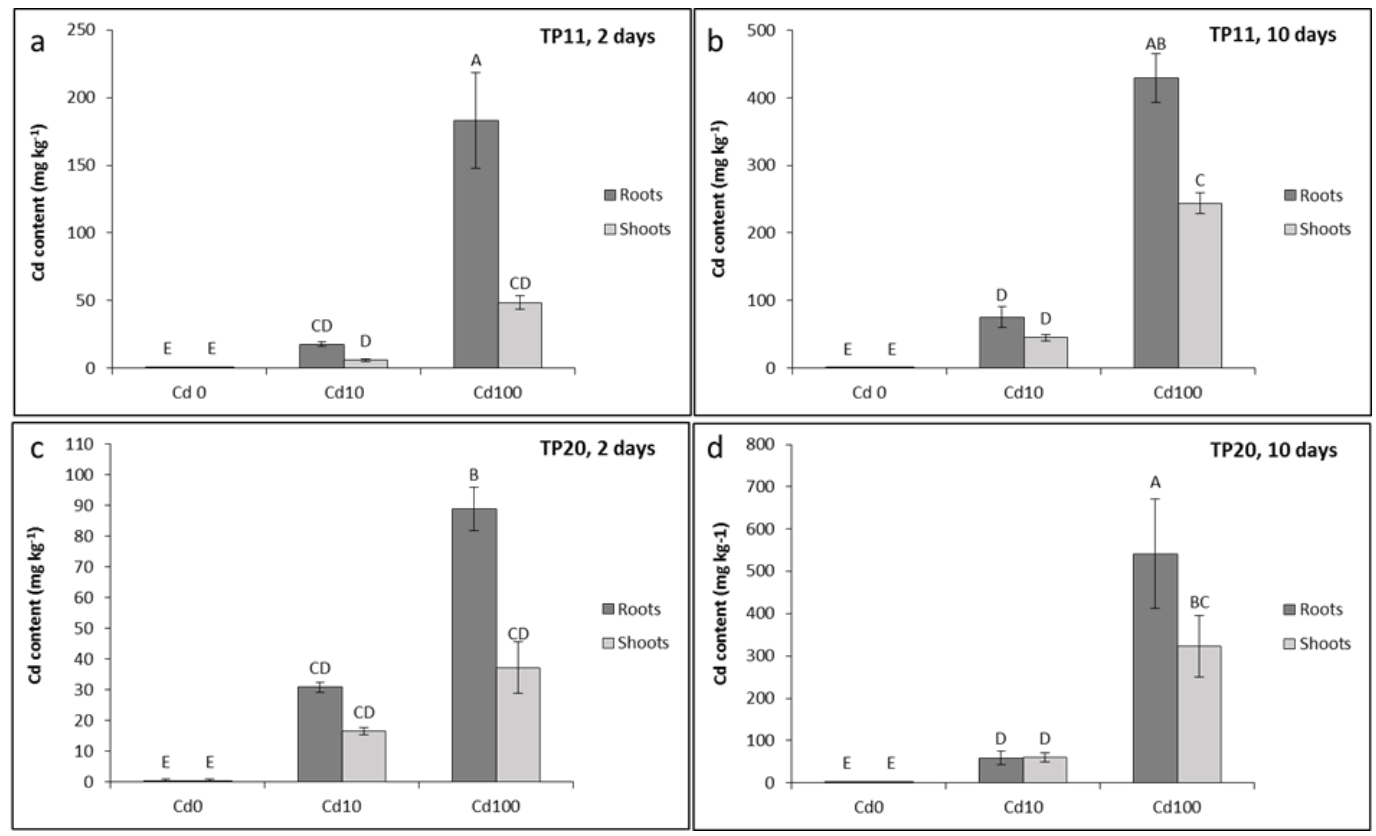

Figure 1. Content of $\mathrm{Cd}$ in the roots and shoots in Populus $\times$ canescens (Aiton Sm.) genotypes TP11 $(\mathbf{a}, \mathbf{b})$ and TP20 (c,d) grown in perlite for 2 or 10 days with or without Cd. Data are presented as the mean $\pm \mathrm{SD}(\mathrm{n}=3)$. Values followed by the same letter(s) are not significantly different according to Tukey's test $(p<0.05)$.

Table 4. Translocation factor $\left[\mathrm{TF}=\mathrm{C}_{\text {aerial }} / \mathrm{C}_{\text {root }}\right]$ in Populus $\times$ canescens (Aiton Sm.) genotypes TP11 and TP20 grown in perlite for 2 or 10 days with or without $C d$.

\begin{tabular}{ccc}
\hline \multicolumn{3}{c}{ Translocation Factor (TF) } \\
\hline 2 days & TP11 & TP20 \\
Cd 10 & 0.34 & 0.54 \\
Cd 100 & 0.27 & 0.42 \\
\hline 10 days & & \\
Cd 10 & 0.61 & 1.06 \\
Cd 100 & 0.57 & 0.63 \\
\hline
\end{tabular}




\subsection{Cadmium Localization in Grey Poplar Plants}

Autoradiography (Figure 2) was used to determine $\mathrm{Cd}$ distribution in different organs in tested grey poplar plants. Using this technique we were able to show that $\mathrm{Cd}$ was localized at the lower metal concentration $(10 \mu \mathrm{M})$ mainly in the root system and stalk of both grey poplar genotypes TP11 and TP20. In plants grown on higher $\mathrm{Cd}$ concentration $(100 \mu \mathrm{M})$, the $\mathrm{Cd}$ activity was transferred mainly into stalks and leaves (leaf veins), while in roots $\mathrm{Cd}$ activity decreased. This can be explained by stomatal opening and high transpiration leading to enhanced $\mathrm{Cd}$ transport into leaves from the veins [48]. Vollenweider et al. [49] also reported that the highest amount of Cd was located in the pectin-rich collenchyma cell walls of the veins. On the other hand, Pietrini et al. [48] showed the presence of $\mathrm{Cd}$ in necrotic areas of willow leaves. Cosio et al. [50] found $\mathrm{Cd}$ both inside the cells and in the cell walls, in the large epidermal cells but also in small epidermal cells, from which it is assumed that $\mathrm{Cd}$ is stored in the less metabolically active parts of leaf cells of T. caerulescens. The authors also report that the intensity of the darkening did not reflect the total concentration of $\mathrm{Cd}$ found in the leaves, therefore, it is difficult to compare autoradiography with real measured values. This confirms the comparison of autoradiography of poplar (Figure 2) with the graphs (Figure 1) in our experiment.

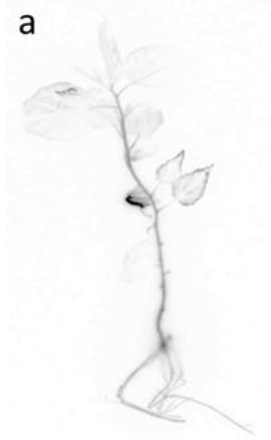

$\mathrm{TP} 11,10 \mu \mathrm{M} \mathrm{Cd}$

b

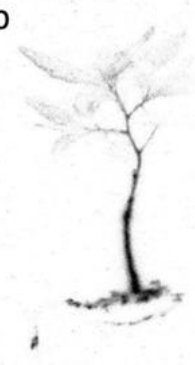

$\mathrm{TP} 11,10 \mu \mathrm{M} \mathrm{Cd}$

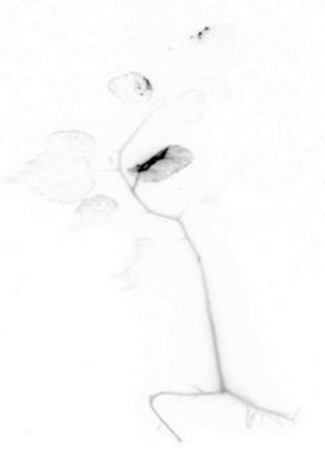

$\mathrm{TP} 11,100 \mu \mathrm{M} \mathrm{Cd}$

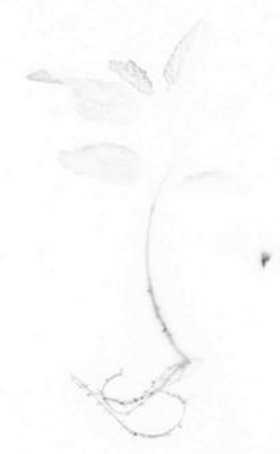

$\mathrm{TP} 20,10 \mu \mathrm{M} \mathrm{Cd}$

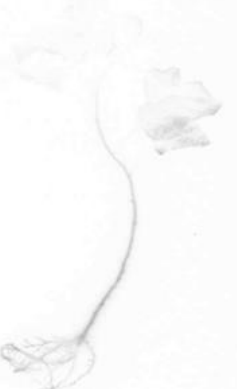

TP20, $100 \mu \mathrm{M} \mathrm{Cd}$

Figure 2. Autoradiography of hydroponically grown Populus $\times$ canescens (Aiton Sm.) plants treated with $\mathrm{Cd}$ for 2 (a) and 10 (b) days. Radioactivity of ${ }^{109} \mathrm{Cd}$ is detectable in different organs of grey poplar.

\subsection{Analysis of Gene Expression Patterns}

To determine how the accumulation of $\mathrm{Cd}$ altered the transcript levels of selected stress-response genes in actively growing grey poplar plants, qRT-PCR was conducted. The gene expression levels in two genotypes (TP11 and TP20) grown in the presence of $0 \mu \mathrm{M} \mathrm{Cd}$ (control), $10 \mu \mathrm{M} \mathrm{Cd}$ and $100 \mu \mathrm{M} \mathrm{Cd}$ for 2 or 10 days were detected in the roots and shoots separately (Table 5).

Chitinases belong to the glycosyl hydrolase family with a wide range of functions, including proper growth and development and resistance towards pathogens, fungi, cold stress and drought stress [51,52]. However, some chitinases are also upregulated by heavy metals [53]. The expression 
patterns of endochitinase 2 (LOC7470435) significantly increased in the roots of both grey poplar genotypes after treatment for 2 days with $10 \mu \mathrm{M} \mathrm{Cd}(6.85 ; 7.20)$ and $100 \mu \mathrm{M}(3.36 ; 4.63)$ compared to the control $(1.15 ; 1.03)$, while in the leaves, up- and downregulation was detected (Table 5). For example, the lowest transcript levels (4.3-fold) were measured in the leaves of TP20 after 2 days of $100 \mu \mathrm{M} \mathrm{Cd}$ treatment, whereas the highest mRNA levels (2.1-fold) were detected in the similarly treated TP11 leaves ( 2 days in $100 \mu \mathrm{M} \mathrm{Cd}$ ). In contrast to our results, Gálusová et al. [54] showed that one of the tested chitinase isoforms was affected by metal stress in roots, while in leaves, the chitinases were relatively more responsive.

12-Oxophytodienoate reductases (OPRs) are a small group of flavin-dependent oxidoreductases in plants with catalytic function in the biosynthesis of jasmonic acid (JA) [55]. However, detailed information describing the mechanisms underlying JA-mediated enhanced plant $\mathrm{Cd}$ tolerance is rare. It has been reported that JA activates genes that might be involved in the signal transduction pathway for $\mathrm{Cu}$ and $\mathrm{Cd}$ and upregulates GSH metabolic genes [56]. Moreover, JA stimulates an increase in ROS during the first hours of exposure to excess $\mathrm{Cu}$ or $\mathrm{Cd}$ in Arabidopsis thaliana (L.) Heynh. [57]. Our results show that with prolonged cultivation time of grey poplar genotypes, the relative expression patterns of OPR1 increased in both plant organs. Significantly higher OPR1 transcript levels were detected in the roots of TP11 and TP20 after 10 days of Cd treatment, especially in TP11 (38.4-fold) grown under $10 \mu \mathrm{M} \mathrm{Cd}$, compared to the control. As in the roots, the level of transcription in the leaves was also upregulated after 10 days of $\mathrm{Cd}$ treatment. The highest upregulation of ORP1 (16.4-fold) was measured in the leaves of TP20 cultivated with $10 \mu \mathrm{M} \mathrm{Cd}$. Similar to our results, Liu et al. [58] showed the upregulation of OPR1 in Arabidopsis seedlings under Pb stress. Based on our analysis, it is conceivable that cross-talk between JA biosynthesis and the $\mathrm{Cd}$ defence mechanisms occurs.

Thaumatin-like proteins (TLPs) are polypeptides that share sequence similarity with thaumatin [59]. Their expression is induced by pathogen stress, but many are also inducible by other stress conditions, including heavy metal stress [60]. In the leaf apoplast of Vigna unguiculata (L.) Walp., Mn toxicity increased the concentration of proteins, which exhibited homology to pathogenesis-related proteins, including thaumatin-like proteins [61]. Similarly, the excess $100 \mu \mathrm{M} \mathrm{Cd}$ supply in our experiment caused an increase in TLP (LOC105129022) transcript levels in the roots of TP20 (7.02-fold) after 2 days of stress. We suggest that this significant change indicates a higher potential for the TP20 genotype to mediate Cd stress.

Photosystem II $10 \mathrm{kDa}$ polypeptide is located at the inner grana thylakoid surface. It is well known that high $\mathrm{Cd}$ concentrations lead to lower values of maximum photochemical efficiency of photosystem II, which was described, for example, by Júnior et al. [62] in the study on young plants of Virola surinamensis (Rol. ex Rottb.) Warb. Interestingly, in our experiment, 10 days of Cd treatment did not alter the level of PSII $10 \mathrm{kDa}$ polypeptide (LOC18095761) transcripts in either of the tested genotypes. A minor decrease in transcripts was observed only after 2 days of $100 \mu \mathrm{M} \mathrm{Cd}$ treatment in both tested genotypes. From these results, we suggest that under long-term stress, poplar plants can effectively reduce the impact of heavy metal toxicity.

Metallothioneins (MTs) are Cys-rich metal chelators. In Vicia faba L. transgenotes, the Arabidopsis gene AtMT2a was shown to play a role in Cd resistance [63]. The results of our experiment show mostly minor, non-significant changes in the level of the MT2a transcript. The only significant increase was found in the roots of TP11 (3.4-fold) after 10 days of $10 \mu \mathrm{M} \mathrm{Cd}$ treatment. Therefore, we hypothesize that $M T 2 a$ may not participate in Cd detoxification in grey poplar.

Glutathione S-transferase expression is induced by a wide range of biotic and abiotic stresses, including pathogens, heavy metals, drought, salt or hormones [64-67]. In Oryza sativa L., the GST proteins might alleviate $\mathrm{Cu}$ toxicity by the binding of free $\mathrm{Cu}^{2+}$ in cells [68], which might be an important mechanism in defence towards heavy metal toxicity. Under Cd stress, the expression patterns of the 20 selected GST genes in Chinese cabbage showed differences in tissue distribution and with environmental changes [69]. However, the GST superfamily is composed of 81 genes in Populus [70]; thus, the mechanisms involved in the response to different stresses should be further 
studied. One of the classes identified was the phi class glutathione S-transferase which was found to reduce levels of oxidative damage and improved resistance to salt and drought stress [67]. Our results revealed several significant changes in GSTF4 transcript levels in response to Cd. After 10 days of Cd treatment, the GSTF4 transcript level significantly increased in the roots of both grey poplar genotypes compared to control plants and compared to the treatment for 2 days. Only in the roots of TP20 did the 2-day treatment with $100 \mu \mathrm{M}$ Cd cause a minor, but significant, increase in GSTF4 transcript levels. Consistent with our results, Kieffer et al. [71] showed in their enzymatic assay that higher GST activity was detected in response to $\mathrm{Cd}$ in the roots but not in the leaves of poplar.

UDP-glucosyltransferase 74E2 (UGT74E2) is a member of the UGTs, which perturb IBA and auxin homeostasis, improve stress tolerance and regulate morphological and physiological stress adaptation mechanisms in A. thaliana [72]. Because Cd negatively affects auxin homeostasis [73], this gene was chosen for analysis in our study. However, our results were less consistent. The induction of transcript levels was found in the leaves of TP11 treated with $10 \mu \mathrm{M} \mathrm{Cd}$ for 2 days and in roots stressed with the same treatment for 10 days compared to control conditions. In contrast, transcript levels decreased in the leaves of both genotypes after 2 and 10 days of $100 \mu \mathrm{M} \mathrm{Cd}$ treatment.

Table 5. Relative gene expression values obtained by semi-quantitative real time RT-PCR for seven candidate genes. The analysis was performed on roots and shoots of Populus $\times$ canescens (Aiton Sm.) genotypes TP11 and TP20 grown in perlite for 2 or 10 days with or without $\mathrm{Cd}$. Data are presented as the mean $\pm \mathrm{SD}(\mathrm{n}=3)$. Values for each single gene followed by the same letter(s) are not significantly different according to Tukey's test $(p<0.05)$.

\begin{tabular}{|c|c|c|c|c|}
\hline & \multicolumn{2}{|c|}{2 Days } & \multicolumn{2}{|c|}{10 Days } \\
\hline & Root & Shoot & Root & Shoot \\
\hline \multicolumn{5}{|c|}{ Endochitinase 2} \\
\hline Control & $1.15 \pm 0.7$ cde & $0.97 \pm 0.5^{\text {cde }}$ & $1.05 \pm 0.2^{\text {cde }}$ & $0.90 \pm 0.2$ cde \\
\hline $10 \mathrm{Cd}$ & $6.85 \pm 0.8^{\mathrm{a}}$ & $1.18 \pm 0.2^{\text {cde }}$ & $1.83 \pm 0.2^{c}$ & $0.47 \pm 0.1^{\mathrm{de}}$ \\
\hline $100 \mathrm{Cd}$ & \multicolumn{4}{|c|}{ TP20 } \\
\hline Control & $1.03 \pm 0.1^{\text {cde }}$ & $0.91 \pm 0.2^{\text {cde }}$ & $1.03 \pm 0.1^{\mathrm{cde}}$ & $0.90 \pm 0.1^{\mathrm{cde}}$ \\
\hline $10 \mathrm{Cd}$ & $7.20 \pm 0.9^{a}$ & $1.60 \pm 0.3^{\mathrm{cd}}$ & $1.40 \pm 0.3^{\text {cde }}$ & $0.72 \pm 0.2$ cde \\
\hline $100 \mathrm{Cd}$ & $4.63 \pm 0.5^{b}$ & $0.21 \pm 0.1^{\mathrm{e}}$ & $1.77 \pm 0.4^{\mathrm{cd}}$ & $0.93 \pm 0.2^{\text {cde }}$ \\
\hline \multicolumn{5}{|c|}{ 12-oxophytodienoate reductase 1} \\
\hline Control & $0.55 \pm 0.1^{g}$ & $1.71 \pm 0.9 \mathrm{fg}$ & $0.92 \pm 0.4^{\mathrm{g}}$ & $1.56 \pm 0.3^{\mathrm{fg}}$ \\
\hline $10 \mathrm{Cd}$ & $1.95 \pm 0.1 \mathrm{fg}$ & $6.09 \pm 1.8^{\text {defg }}$ & $35.36 \pm 8.4^{\mathrm{a}}$ & $13.89 \pm 1.7^{\mathrm{c}}$ \\
\hline $100 \mathrm{Cd}$ & $4.83 \pm 1.8^{\text {defg }}$ & $\begin{array}{r}2.10 \pm 0.1^{\mathrm{fg}} \\
\mathrm{TP} 20\end{array}$ & $24.26 \pm 3.9^{b}$ & $8.00 \pm 1.1^{\text {cdef }}$ \\
\hline Control & $0.99 \pm 0.4 \mathrm{~g}$ & $1.60 \pm 0.6^{\mathrm{fg}}$ & $0.87 \pm 0.1^{\mathrm{g}}$ & $1.59 \pm 0.5 \mathrm{fg}$ \\
\hline $10 \mathrm{Cd}$ & $3.00 \pm 0.7 \mathrm{efg}$ & $0.93 \pm 0.1^{\mathrm{g}}$ & $6.57 \pm 1.5^{\text {defg }}$ & $26.03 \pm 0.9^{b}$ \\
\hline $100 \mathrm{Cd}$ & $9.34 \pm 0.9$ cde & $1.97 \pm 0.3 \mathrm{fg}$ & $9.87 \pm 1.9^{\mathrm{cd}}$ & $10.24 \pm 0.9^{\mathrm{cd}}$ \\
\hline \multicolumn{5}{|c|}{ thaumatin-like protein } \\
\hline Control & $0.95 \pm 0.4^{b}$ & $1.79 \pm 0.2^{b}$ & $0.97 \pm 0.5^{b}$ & $2.25 \pm 1.5^{b}$ \\
\hline $10 \mathrm{Cd}$ & $0.25 \pm 0.1^{b}$ & $0.25 \pm 0.2^{b}$ & $1.32 \pm 0.4^{b}$ & $1.24 \pm 1.0^{b}$ \\
\hline $100 \mathrm{Cd}$ & $1.35 \pm 0.3^{b}$ & $\begin{array}{r}1.75 \pm 1.4^{\mathrm{b}} \\
\text { TP20 }\end{array}$ & $0.95 \pm 0.2^{b}$ & $1.36 \pm 0.6^{\mathrm{b}}$ \\
\hline Control & $0.90 \pm 0.1^{b}$ & $1.85 \pm 0.6^{b}$ & $0.91 \pm 0.2^{b}$ & $1.81 \pm 0.3^{b}$ \\
\hline $10 \mathrm{Cd}$ & $0.47 \pm 0.2^{b}$ & $2.24 \pm 0.9^{b}$ & $0.92 \pm 0.3^{b}$ & $1.56 \pm 0.8^{b}$ \\
\hline $100 \mathrm{Cd}$ & $6.32 \pm 1.2^{\mathrm{a}}$ & $0.29 \pm 0.1^{b}$ & $1.20 \pm 0.6^{b}$ & $1.54 \pm 0.6^{b}$ \\
\hline \multicolumn{5}{|c|}{$\begin{array}{c}\text { photosystem II } 10 \mathrm{kDa} \text { polypeptide } \\
\text { TP11 }\end{array}$} \\
\hline Control & - & $1.42 \pm 1.1^{\mathrm{abc}}$ & - & $1.23 \pm 0.5^{\mathrm{abc}}$ \\
\hline
\end{tabular}


Table 5. Cont.

\begin{tabular}{|c|c|c|c|c|}
\hline & \multicolumn{2}{|c|}{2 Days } & \multicolumn{2}{|c|}{10 Days } \\
\hline & Root & Shoot & Root & Shoot \\
\hline $10 \mathrm{Cd}$ & - & $1.88 \pm 0.3^{\mathrm{ab}}$ & - & $2.25 \pm 0.2^{\mathrm{ab}}$ \\
\hline $100 \mathrm{Cd}$ & - & $\begin{array}{r}0.73 \pm 0.1^{b c} \\
\text { TP20 }\end{array}$ & - & $2.43 \pm 1.1^{\mathrm{a}}$ \\
\hline Control & - & $1.25 \pm 0.6^{\mathrm{abc}}$ & - & $1.17 \pm 0.1^{\mathrm{abc}}$ \\
\hline $10 \mathrm{Cd}$ & - & $0.78 \pm 0.1^{b c}$ & - & $2.34 \pm 0.3^{\mathrm{a}}$ \\
\hline $100 \mathrm{Cd}$ & - & $0.04 \pm 0.0^{\mathrm{c}}$ & - & $1.20 \pm 0.1^{\mathrm{abc}}$ \\
\hline \multicolumn{5}{|c|}{ Metallothionein 2a } \\
\hline Control & $2.86 \pm 1.2^{\text {bcdef }}$ & $1.10 \pm 0.4^{\text {defgh }}$ & $2.84 \pm 1.0$ bcdefg & $1.11 \pm 0.5^{\text {defgh }}$ \\
\hline $10 \mathrm{Cd}$ & $0.74 \pm 0.6^{\text {efgh }}$ & $1.23 \pm 0.2^{\text {cdefgh }}$ & $9.68 \pm 1.8^{a}$ & $1.42 \pm 0.3^{\text {bcdefgh }}$ \\
\hline $100 \mathrm{Cd}$ & $3.50 \pm 1.3^{b}$ & $\begin{array}{r}0.77 \pm 0.2^{\text {defgh }} \\
\text { TP20 }\end{array}$ & $2.98 \pm 0.7^{\mathrm{bcd}}$ & $1.05 \pm 0.6^{\text {defgh }}$ \\
\hline Control & $2.74 \pm 0.5^{\text {bcdefg }}$ & $1.14 \pm 0.6^{\text {defgh }}$ & $2.90 \pm 1.3$ bcde & $1.04 \pm 0.1^{\text {defgh }}$ \\
\hline $10 \mathrm{Cd}$ & $0.84 \pm 0.2$ defgh & $0.63 \pm 0.2 \mathrm{gh}$ & $3.43 \pm 0.5^{b c}$ & $1.23 \pm 0.1^{\text {cdefgh }}$ \\
\hline $100 \mathrm{Cd}$ & $1.66 \pm 0.1$ bcdefgh & $0.07 \pm 0.0^{h}$ & $2.10 \pm 0.1$ bcdefgh & $0.66 \pm 0.0 \mathrm{fgh}$ \\
\hline \multicolumn{5}{|c|}{ phi class glutathione S-transferase } \\
\hline Control & $1.90 \pm 0.7^{\mathrm{d}}$ & $1.04 \pm 0.1^{\mathrm{d}}$ & $1.91 \pm 0.8^{\mathrm{d}}$ & $1.24 \pm 0.7^{\mathrm{d}}$ \\
\hline $10 \mathrm{Cd}$ & $2.97 \pm 0.4^{\mathrm{d}}$ & $3.92 \pm 0.1^{d}$ & $20.43 \pm 0.9^{a}$ & $0.94 \pm 0.2^{\mathrm{d}}$ \\
\hline $100 \mathrm{Cd}$ & $1.33 \pm 0.8^{\mathrm{d}}$ & $\begin{array}{r}2.75 \pm 0.2^{\mathrm{d}} \\
\text { TP20 }\end{array}$ & $15.65 \pm 1.6^{b}$ & $0.05 \pm 0.4^{\mathrm{d}}$ \\
\hline Control & $1.80 \pm 0.2^{\mathrm{d}}$ & $1.21 \pm 0.9^{d}$ & $1.82 \pm 0.4^{\mathrm{d}}$ & $1.12 \pm 0.5^{\mathrm{d}}$ \\
\hline $10 \mathrm{Cd}$ & $2.89 \pm 0.8^{\mathrm{d}}$ & $2.97 \pm 0.3^{d}$ & $16.03 \pm 1.3^{b}$ & $2.59 \pm 1.5^{\mathrm{d}}$ \\
\hline $100 \mathrm{Cd}$ & $8.50 \pm 4.9^{c}$ & $2.21 \pm 0.0^{\mathrm{d}}$ & $17.50 \pm 1.3^{\mathrm{ab}}$ & $1.99 \pm 0.9^{d}$ \\
\hline \multicolumn{5}{|c|}{ Uridine diphosphate glycosyltransferase 74E2 } \\
\hline & & TP11 & & \\
\hline Control & $1.02 \pm 0.1$ defg & $1.72 \pm 0.1^{\text {cdef }}$ & $1.04 \pm 0.3$ defg & $1.76 \pm 0.5^{\mathrm{cdef}}$ \\
\hline $10 \mathrm{Cd}$ & $1.13 \pm 0.4^{\text {defg }}$ & $3.73 \pm 0.4^{\mathrm{ab}}$ & $4.98 \pm 1.2^{\mathrm{a}}$ & $0.81 \pm 0.2$ efg \\
\hline $100 \mathrm{Cd}$ & $1.55 \pm 0.2^{\text {cdefg }}$ & $\begin{array}{r}1.33 \pm 0.3^{\text {cdefg }} \\
\text { TP20 }\end{array}$ & $2.32 \pm 0.5^{c d}$ & $0.33 \pm 0.1 \mathrm{~g}$ \\
\hline Control & $1.01 \pm 0.1$ defg & $1.81 \pm 0.7$ cde & $1.01 \pm 0.1$ defg & $1.73 \pm 0.2^{\text {cdef }}$ \\
\hline $10 \mathrm{Cd}$ & $1.05 \pm 0.2^{\text {defg }}$ & $1.17 \pm 0.3^{\text {defg }}$ & $2.56 \pm 0.8^{b c}$ & $2.60 \pm 0.4^{b c}$ \\
\hline $100 \mathrm{Cd}$ & $1.36 \pm 0.5^{\text {cdefg }}$ & $0.45 \pm 0.1 \mathrm{fg}$ & $1.37 \pm 0.2^{\text {cdefg }}$ & $1.39 \pm 0.2^{\text {cdefg }}$ \\
\hline
\end{tabular}

\section{Materials and Methods}

\subsection{Plant Material and In Vitro Culture Establishment}

For this study, two individuals of $P$. canescens originating from a unique grey poplar population located in Dyjákovice village in the Czech Republic were selected as source trees. Branches were collected in March 2016 and immediately stored in a container at $4{ }^{\circ} \mathrm{C}$. Twigs with dormant axillary buds were rinsed with running tap water for $30 \mathrm{~min}$, surface disinfected with $1 \%$ sodium hypochlorite $(v / v)$ for $20 \mathrm{~min}, 50 \%$ Korsolex plus (v/v) for $20 \mathrm{~min}$, sterile distilled water for $20 \mathrm{~min}$, and $1 \% \mathrm{HgCl}_{2}$ $(w / v)$ for $20 \mathrm{~min}$ and finally rinsed three times with sterile distilled water for $15 \mathrm{~min}$. The sterile dormant buds were then placed into glass jars containing $50 \mathrm{~mL}$ modified agar MS medium [74] supplemented with $10 \mathrm{mg} \mathrm{L}^{-1}$ glutamine, $2 \mathrm{mg} \mathrm{L}^{-1}$ glycine, $0.1 \mathrm{mg} \mathrm{L}^{-1}$ indole-3-butyric acid (IBA), $0.2 \mathrm{mg} \mathrm{L}^{-1}$ 6-benzylaminopurine (BAP), $30 \mathrm{~g} \mathrm{~L}^{-1}$ sucrose, and $6 \mathrm{~g} \mathrm{~L}^{-1}$ agar at a $\mathrm{pH}$ of 5.8 for the induction of organogenesis. Explants were grown under controlled conditions at a photon flux density of $30 \mu \mathrm{mol} \mathrm{m} \mathrm{m}^{-2} \mathrm{~s}^{-1}$ (16/8 day/night period) at $2{ }^{\circ} \mathrm{C}$ for 30 days. Once shoots had elongated from axillary buds, they were excised and transferred for multiplication into the same modified MS agar 
medium used for induction. Explants were cultured in glass jars as previously described. The shoots were subcultured every four weeks.

\subsection{Root Induction and Acclimatization}

The single grey poplar shoots were individually rooted on MS medium that did not contain any growth regulators for the induction of rhizogenesis. In total, each genotype was represented by 25 explants for the experiment. After four weeks, the rooted shoots were transferred into perlite at temperature $22 \pm 2{ }^{\circ} \mathrm{C}$ for 14 days for acclimatization. High humidity was maintained by covering the pots with plastic sheets. The plants were watered with 1/10 strength MS medium. After acclimatization, fourteen-day-old poplar plantlets were treated with $10 \mu \mathrm{M}$ or $100 \mu \mathrm{M} \mathrm{CdCl}$. A concentration of $100 \mu \mathrm{M}$ Cd was chosen to provoke a fast response to stressful conditions. Untreated plants were used as a control. Samples were collected 2 and 10 days after treatment for all analyses and measurements.

\subsection{DNA Extraction, PCR and Genotyping}

DNA was extracted from $20 \mathrm{mg}$ of lyophilized leaves from source trees (TP11 and TP20) using a DNeasy Plant Mini Kit (Qiagen, Germantown, MD, USA) with the protocol provided by the manufacturer. The concentration and purity of DNA was determined using a NanoPhotometer (Implen, München, Germany). DNA was stored at $4{ }^{\circ} \mathrm{C}$.

For polymerase chain reactions (PCRs), fifteen nuclear microsatellite loci, WPMS5, WPMS15, WPMS16, WPMS18, WPMS19, WPMS20, ORPM14, ORPM16, ORPM20, ORPM30, ORPM60, ORPM127, ORPM193, ORPM220 and ORPM312, were used that were formerly described by [75-79]. The PCR programme, conditions and multiplex arrangement were performed according to Pokorna et al. [80]. Reactions were performed in a Veriti Thermal cycler programmed for an initial melting at $94{ }^{\circ} \mathrm{C}$ for 3 min followed by 35 cycles at $94{ }^{\circ} \mathrm{C}$ for $45 \mathrm{~s}$ and $55^{\circ} \mathrm{C}$ for $45 \mathrm{~s}$. A final extension step at $72{ }^{\circ} \mathrm{C}$ for 20 min was performed. Then, $1 \mu \mathrm{L}$ of PCR product was mixed with $0.4 \mu \mathrm{L}$ of Gene Scan ${ }^{\mathrm{TM}} 600$ LIZ $^{\circledR}$ internal size standard (Applied Biosystems, Foster City, CA, USA) and $11 \mu \mathrm{L}$ of formamide (Hi-Di ${ }^{\mathrm{TM}}$ Formamide, Foster City, CA, Applied Biosystems). After denaturation at $94{ }^{\circ} \mathrm{C}$ for $3 \mathrm{~min}$ and immediate chilling on ice, the products were analysed with capillary gel electrophoresis using a genetic analyser 3500 (Applied Biosystems, Foster City, CA, USA). The detection of the PCR product was enabled by the fluorescent label attached to the $5^{\prime}$ end of the forward primer. Allele calling was performed using GeneMapper ${ }^{\circledR} 4.1$ software provided by Applied Biosystems. Allele binning was performed manually after plotting the fragment size distribution for each locus [81].

\subsection{RNA Extraction and cDNA Synthesis}

Total RNA was extracted from mature grey poplar plants (control, 10 and $100 \mu \mathrm{M} \mathrm{Cd}$ ), stressed roots and shoots were collected separately from three different plantlets at the end of days 2 and 10. Roots and shoots were frozen in liquid nitrogen and stored at $-80^{\circ} \mathrm{C}$ until analysis. RNA was extracted from homogenized plant material (approximately $100 \mathrm{mg}$ of fresh weight) using the RNeasy Plant Mini Kit (Qiagen, Hilden, Germany) according to the manufacturer's instructions. RNA concentration was measured by the MaestroNano Pro (MaestroGen, Las Vegas, NV, USA). Extracted RNA ( $2 \mu \mathrm{g})$ was reverse transcribed by M-MLV Reverse Transcriptase (Promega corporation, Madison, WI, USA), while oligodT primers were used for first-strand cDNA synthesis for each sample. According to the manufacturer's protocol, RNA templates with primers were preincubated for 5 min at $75{ }^{\circ} \mathrm{C}$ and immediately cooled on ice. The RT-PCR premix was then added, and the transcription reaction was run at $42{ }^{\circ} \mathrm{C} / 60 \mathrm{~min}, 70{ }^{\circ} \mathrm{C} / 5 \mathrm{~min}$, and $10^{\circ} \mathrm{C}$ until further manipulation.

\subsection{Gene Expression Analysis}

The quantitative real-time RT-PCR analyses were carried out using GoTaq qPCR Master Mix (Promega Corporation, Madison, WI, USA) mix in a LightCycler 96 (Roche, Mannheim, Germany). The analyses were performed using two reference genes and seven target genes reported previously for 
poplar trees (Table 6). The primers were designed using Primer3 software (Rozen and Skaletsky 2000, Boston, MA, USA) according to the following parameters: 100-200 bp product size, 19-22 bp primer length, 58-60 ${ }^{\circ} \mathrm{C}$ melting temperature (Tm) and $45-55 \%$ GC content. The thermal cycling conditions were assessed $120 \mathrm{~s}$ at $95^{\circ} \mathrm{C}$ for preincubation, followed by amplification for 45 cycles of $95^{\circ} \mathrm{C}$ for $10 \mathrm{~s}$, $60^{\circ} \mathrm{C}$ for $10 \mathrm{~s}, 72^{\circ} \mathrm{C}$ for $10 \mathrm{~s}$, melting curve was assessed at $95^{\circ} \mathrm{C}$ for $10 \mathrm{~s}$, followed by $65^{\circ} \mathrm{C}$ for $60 \mathrm{~s}$ and $97^{\circ} \mathrm{C}$ for $1 \mathrm{~s}$. Analysis of all samples was performed with three technical replicates. Quantifications were performed according to the $\Delta \mathrm{Ct}$ method, and the relative gene expression levels were normalized by the expression levels of the $18 \mathrm{~S}$ ribosomal RNA and elongation factor 1- $\alpha$ genes, as internal standards [82].

Table 6. The gene name, accession number, description, primer sequence and reference.

\begin{tabular}{|c|c|c|c|c|}
\hline Gene & Accession Number & Gene Description & Primer Sequence $\left(5^{\prime}-3^{\prime}\right)$ & Reference \\
\hline LOC112328551 & XR_002983567 & 18S Ribosomal RNA & $\begin{array}{l}\text { F: AGAAACGGCTACCACATCCAA } \\
\text { R: CCAGACTTGCCCTCCAATGG }\end{array}$ & [83] \\
\hline LOC18109220 & EF147878.1 & Elongation factor $1-\alpha$ & $\begin{array}{l}\text { F: CCACACCTGTCACATTGCTG } \\
\text { R: ACCAGCATCACCGTTCTTCAG }\end{array}$ & [84] \\
\hline LOC7470435 & XM_002306184.3 & Endochitinase 2 & $\begin{array}{l}\text { F: TACGGGCAATGTGGAAAAGC } \\
\text { R: ATTGTGGCATGAGGGCTTTG }\end{array}$ & [85] \\
\hline OPR1 & NM_106318.4 & $\begin{array}{l}\text { 12-Oxophytodienoate } \\
\text { reductase } 1\end{array}$ & $\begin{array}{l}\text { F: CGGACAAGCAGGAGACTCAAA } \\
\text { R: CCACCGTCTTCATTCTTGGC }\end{array}$ & [83] \\
\hline UGT74E2 & NM_100448.4 & $\begin{array}{l}\text { Uridine diphosphate } \\
\text { glycosyltransferase 74E2 }\end{array}$ & $\begin{array}{l}\text { F: CACAAATCCGTGGGATGCTT } \\
\text { R: TCTGTCCACTGTGGCATTGC }\end{array}$ & [83] \\
\hline LOC105129022 & XM_011030918 & Thaumatin-like protein & $\begin{array}{l}\text { F: ACCACACAAGCACGCATTTG } \\
\text { R: TGAACCATAGCCTTGGCATG }\end{array}$ & [85] \\
\hline LOC18095761 & 18095761 & $\begin{array}{l}\text { Photosystem II } 10 \mathrm{kDa} \\
\text { polypeptide }\end{array}$ & $\begin{array}{l}\text { F: ATGGTGCTAATGTGGATGGC } \\
\text { R: AACAGCCCAGATTAGCAAGC }\end{array}$ & [86] \\
\hline MT2a & AY594297.1 & Metallothionein 2a & $\begin{array}{c}\text { F: ATCATCGCATCGACGGATTG } \\
\text { R: CCAGAGCTGCAAATCCAAGAAG }\end{array}$ & [87] \\
\hline GSTF4 & GQ377243.1 & $\begin{array}{l}\text { Phi class glutathione } \\
\text { S-transferase }\end{array}$ & $\begin{array}{l}\text { F: CTTAGCCTCGTTTTCCTCCA } \\
\text { R: CTTAGCCTCGTTTTCCTCCA }\end{array}$ & [88] \\
\hline
\end{tabular}

\subsection{Measurement of $\mathrm{Cd}$ and Selected Element Contents}

The content of $\mathrm{Cd}$ and selected minerals $(\mathrm{K}, \mathrm{Ca}, \mathrm{Mg}, \mathrm{Zn})$ in the roots and shoots of grey poplar samples was determined using ICP-OES (Inductively Coupled Plasma Optical Emission Spectrometry, Varian 725-ES, Agilent Technologies, Santa Clara, USA). Dried material was milled to fine powder, whereas each sample (100 mg fresh weight) was mineralized with $5 \mathrm{~mL}$ of nitric acid [67\% $\left.\mathrm{HNO}_{3}(w / v)\right]$ and $1 \mathrm{~mL}$ of hydrogen peroxide $\left[30 \% \mathrm{H}_{2} \mathrm{O}_{2}(w / v)\right]$ in a microwave digestion system (Speedwave4, Berghof Products Instruments, Eningen, Germany) at $20{ }^{\circ} \mathrm{C}$ for $15 \mathrm{~min}$. Cooled samples were diluted with distilled water, and the element content was determined by ICP-OES (Varian 725-ES, Agilent Technologies, Santa Clara, USA). Three biological replicates of control and Cd-treated plants were analysed in two individual sets of experiments.

\subsection{Chlorophyll Measurement}

Fresh shoot tissues (100 mg) were extracted in $80 \%$ acetone $\left(w / v 1 \mathrm{~g} \mathrm{FW} 20 \mathrm{~mL}^{-1}\right)$ and centrifuged for $14,000 \mathrm{rcf}$ for $5 \mathrm{~min}$ at $4{ }^{\circ} \mathrm{C}$. The supernatant was separated, and $0.2 \mathrm{~mL}$ of the supernatant was mixed with $0.8 \mathrm{~mL}$ of acetone. The solution mixture was analysed for chlorophyll $a$, chlorophyll $b$ and chlorophyll $a+b$ contents by recording the absorbance at 663 (chlorophyll $a$ ) and 647 (chlorophyll $b$ ) using a UV-VIS spectrophotometer (VIS-7236, Rayleigh, Beijing Beifen-Ruili Analytical Instrument, Beijing, China). The contents of photosynthetic pigments were calculated according to [89].

\subsection{Autoradiography Method}

The grey poplar plantlets (genotypes TP11 and TP20) were transferred from in vitro conditions to the greenhouse and cultivated in the modified Hoagland medium [90]. The hydroponic medium with a pH adjusted to 5.0 contained $4 \mathrm{mM} \mathrm{CaCl}_{2}, 2 \mathrm{mM} \mathrm{K}_{2} \mathrm{SO}_{4}, 2 \mathrm{mM} \mathrm{NH}_{4} \mathrm{NO}_{3}, 2 \mathrm{mM} \mathrm{NaH}_{2} \mathrm{PO}_{4}, 1.5 \mathrm{mM}$ 
$\mathrm{MgSO}_{4}, 4 \mathrm{mM} \mathrm{NaNO}, 4 \mathrm{mM} \mathrm{NH}_{4} \mathrm{Cl}, 0.2 \mathrm{mM} \mathrm{FeSO}_{4}, 138.8 \mu \mathrm{M} \mathrm{H}_{3} \mathrm{BO}_{3}, 20.8 \mu \mathrm{M} \mathrm{MnSO}_{4}, 2.3 \mu \mathrm{M}$ $\mathrm{ZnSO}_{4}, 3.3 \mu \mathrm{M} \mathrm{CuSO}_{4}$ and $0.2 \mu \mathrm{M} \mathrm{Na}_{2} \mathrm{MoO}_{4}$ (PENTA Ltd., Prague, Czech Republic). The plants were maintained at $23{ }^{\circ} \mathrm{C}$ with a relative humidity of approximately $60 \%$ and were irradiated with $16 \mathrm{~h}$ of light (average irradiation of $72 \mu \mathrm{mol} \mathrm{m}^{-2} \mathrm{~s}^{-1}$-at the plant surface, with horizontal differences in irradiation less than $20 \%$, sodium discharge lamps at $400 \mathrm{~W}$, Thorn Radbay, Durhamgate, UK). Two-week-old plants were used for the experiments.

For the experiment the modified Hoagland medium contain 0.01 or $0.1 \mathrm{mM} \mathrm{Cd}\left(\mathrm{NO}_{3}\right)_{2} \times 4 \mathrm{H}_{2} \mathrm{O}$ (PENTA Ltd., Czech Republic) and volume activity of $6.517 \mathrm{MBq} / \mathrm{L}$ of ${ }^{109} \mathrm{Cd}$ as $\mathrm{CdCl}_{2}$ in $\mathrm{HCl}$ water solution (3g HCl/L) (specific activity $4.591 \mathrm{MBq} / \mathrm{g}$, EUROSTANDARD CZ Ltd., Prague, Czech Republic) was used. After exposure ( 2 and 10 days), the roots of the plants were washed with distilled water, EDTA (concentration $0.1 \mathrm{mM}$ ) and distilled water and then the plants were pressed and dried (between two filter papers, $25^{\circ} \mathrm{C}$, ca 1 week). The pressed plants were transferred to an Exposure Cassette (Amersham Biosciences, Little Chalfont, UK) $(24 \times 30 \mathrm{~cm})$ and put on the Kodak Storage Phosphor Screen S 230. The screen was exposed during $120 \mathrm{~h}$ ( 2 days Cd treatment) or $24 \mathrm{~h}$ (10 days Cd treatment) and scanned by Typhoon Imager (Amersham Biosciences, Little Chalfont, UK). The data were visualized by the program Image Quant TL.

\subsection{Data Analysis}

All analyses were performed in three biological replicates using two-way ANOVA and Tukey's test (Minitab) to evaluate the significant differences $(p<0.05)$ among the Cd treatments $(0 \mu \mathrm{M}, 10 \mu \mathrm{M}$ and $100 \mu \mathrm{M})$.

\section{Conclusions}

To reveal the genetic differentiation between two selected grey poplar genotypes, microsatellite analysis was performed. Considering the toxicity of $\mathrm{Cd}$ and the effects of $\mathrm{Cd}$ on plant growth, the present data demonstrated that grey poplar cultures are highly tolerant to metal stress. However, the chlorophyll content in the shoots significantly decreased in Cd-treated plants. According to the mineral concentration, the two poplar genotypes, TP11 and TP20, showed variation in mineral uptake after Cd treatment. Cadmium accumulation was higher in the roots than in the shoots, and after 10 days of exposure to $10 \mu \mathrm{M}$ $\mathrm{Cd}$, genotype TP20 translocated comparable amounts of $\mathrm{Cd}$ to the roots and shoots. This accumulation was reflected by a TF value greater than 1 , which indicates that $\mathrm{Cd}$ tolerance in genotype TP20 was greater than that in TP11 under the current experimental conditions. However, autoradiography did not confirm differences in $\mathrm{Cd}$ accumulation between both tested cultivars. According to the expression of stress-response genes, the most significant change was observed in the amount of endochitinase 2 , 12-oxophytodienoate reductase 1 and phi class glutathione S-transferase transcripts.

The present data demonstrated that in vitro cultures of cuttings are useful for assessing the ability of different poplar genotypes to tolerate $\mathrm{Cd}$ and for assessing the mechanisms underlying $\mathrm{Cd}$ tolerance. Furthermore, studies on metal tolerance based on the association of physiological and molecular data represent an initial effective method for field trials on metal-polluted soils.

Author Contributions: Conceptualization, M.K.; methodology, M.K. and P.S.; software, E.P.; validation, M.K. and J.C.; formal analysis, J.C.; investigation, M.K. and J.C.; resources, P.M.; data curation, M.K., J.C. and E.P.; writing — original draft preparation, M.K.; writing — review and editing, E.P., P.S. and P.M.; visualization, M.K.; supervision, P.M.; project administration, M.K.; funding acquisition, P.S. and P.M. All authors have read and agreed to the published version of the manuscript.

Funding: This research was funded by the Ministry of Agriculture of the Czech Republic, Institutional Support MZE-RO0118 and project no. QK1810258 and by the Ministry of Education, Youth and Sports of CR from European Regional Development Fund-Project "Centre for Experimental Plant Biology": No. CZ.02.1.01/0.0/0.0/16_019/0000738.

Acknowledgments: We thank to Ludka Cizkova who provided grey poplar trees from Dyjakovice.

Conflicts of Interest: The authors declare no conflict of interest. 


\section{References}

1. Wu, D.; Yamaji, N.; Yamane, M.; Kashino-Fujii, M.; Sato, K.; Ma, J.F. The HvNramp5 Transporter Mediates Uptake of Cadmium and Manganese, But Not Iron. Plant Physiol. 2016, 172, 1899-1910. [CrossRef] [PubMed]

2. Liu, H.; Zhao, H.; Wu, L.; Liu, A.; Zhao, F.-J.; Xu, W. Heavy metal ATPase 3 (HMA3) confers cadmium hypertolerance on the cadmium/zinc hyperaccumulatorSedum plumbizincicola. New Phytol. 2017, 215, 687-698. [CrossRef] [PubMed]

3. Zhang, J.; Martinoia, E.; Lee, Y. Vacuolar Transporters for Cadmium and Arsenic in Plants and their Applications in Phytoremediation and Crop Development. Plant Cell Physiol. 2018, 59, 1317-1325. [CrossRef]

4. Garmash, E.; Golovko, T.K. Effect of cadmium on growth and respiration of barley plants grown under two temperature regimes. Russ. J. Plant Physiol. 2009, 56, 343-347. [CrossRef]

5. Li, S.; Yang, W.; Yang, T.; Chen, Y.; Ni, W. Effects of Cadmium Stress on Leaf Chlorophyll Fluorescence and Photosynthesis ofElsholtzia argyi-A Cadmium Accumulating Plant. Int. J. Phytoremediat. 2014, 17, 85-92. [CrossRef] [PubMed]

6. Lin, L.; Zhou, W.; Dai, H.; Cao, F.; Zhang, G.; Wu, F. Selenium reduces cadmium uptake and mitigates cadmium toxicity in rice. J. Hazard. Mater. 2012, 236, 343-351. [CrossRef]

7. Nazar, R.; Iqbal, N.; Masood, A.; Khan, M.I.R.; Syeed, S.; Khan, N.A. Cadmium Toxicity in Plants and Role of Mineral Nutrients in Its Alleviation. Am. J. Plant Sci. 2012, 3, 1476-1489. [CrossRef]

8. Sharma, P.; Jha, A.B.; Dubey, R.S.; Pessarakli, M. Reactive Oxygen Species, Oxidative Damage, and Antioxidative Defense Mechanism in Plants under Stressful Conditions. J. Bot. 2012, 2012, 1-26. [CrossRef]

9. Cui, W.; Wang, H.; Song, J.; Cao, X.; Rogers, H.J.; Francis, D.; Jia, C.; Sun, L.; Hou, M.; Yang, Y.; et al. Cell cycle arrest mediated by Cd-induced DNA damage in Arabidopsis root tips. Ecotoxicol. Environ. Saf. 2017, 145, 569-574. [CrossRef]

10. DalCorso, G.; Farinati, S.; Maistri, S.; Furini, A. How Plants Cope with Cadmium: Staking All on Metabolism and Gene Expression. J. Integr. Plant Biol. 2008, 50, 1268-1280. [CrossRef] [PubMed]

11. Yamaguchi, H.; Fukuoka, H.; Arao, T.; Ohyama, A.; Nunome, T.; Miyatake, K.; Negoro, S. Gene expression analysis in cadmium-stressed roots of a low cadmium-accumulating solanaceous plant, Solanum torvum. J. Exp. Bot. 2009, 61, 423-437. [CrossRef]

12. Garbisu, C.; Hernández-Allica, J.; Barrutia, O.; Alkorta, I.; Becerril, J.M. Phytoremediation: A Technology Using Green Plants to Remove Contaminants from Polluted Areas. Rev. Environ. Health 2002, 17, 173-188. [CrossRef] [PubMed]

13. Reeves, R.D.; Van Der Ent, A.; Baker, A.J.M. Global Distribution and Ecology of Hyperaccumulator Plants. In Agromining: Farming for Metals; Springer: Cham, Switzerland, 2017; pp. 75-92.

14. Brown, S.L.; Chaney, R.L.; Angle, J.S.; Baker, A.J.M. Zinc and Cadmium Uptake by Hyperaccumulator Thlaspi caerulescens and Metal Tolerant Silene vulgaris Grown on Sludge-Amended Soils. Environ. Sci. Technol. 1995, 29, 1581-1585. [CrossRef]

15. Hernández-Allica, J.; Becerril, J.M.; Zárate, O.; Garbisu, C. Assessment of the Efficiency of a Metal Phytoextraction Process with Biological Indicators of Soil Health. Plant Soil 2006, 281, 147-158. [CrossRef]

16. Epelde, L.; Becerril, J.M.; Kowalchuk, G.A.; Deng, Y.; Zhou, J.; Garbisu, C. Impact of Metal Pollution and Thlaspi caerulescens Growth on Soil Microbial Communities. Appl. Environ. Microbiol. 2010, 76, 7843-7853. [CrossRef]

17. Broadhurst, C.L.; Chaney, R.L. Growth and Metal Accumulation of an Alyssum murale Nickel Hyperaccumulator Ecotype Co-cropped with Alyssum montanum and Perennial Ryegrass in Serpentine Soil. Front. Plant Sci. 2016, 7, 451. [CrossRef] [PubMed]

18. Huang, Y.; Miyauchi, K.; Inoue, C.; Endo, G. Development of suitable hydroponics system for phytoremediation of arsenic-contaminated water using an arsenic hyperaccumulator plant Pteris vittata. Biosci. Biotechnol. Biochem. 2015, 80, 1-5. [CrossRef]

19. Tlustoš, P.; Břendová, K.; Száková, J.; Najmanová, J.; Koubová, K. The long-term variation of Cd and Zn hyperaccumulation by Noccaea spp and Arabidopsis halleri plants in both pot and field conditions. Int. J. Phytoremediat. 2016, 18, 110-115. [CrossRef]

20. He, J.; Ma, C.; Ma, Y.; Li, H.; Kang, J.; Liu, T.; Polle, A.; Peng, C.; Luo, Z.-B. Cadmium tolerance in six poplar species. Environ. Sci. Pollut. Res. 2013, 20, 163-174. [CrossRef] 
21. Martinsen, G.D.; Whitham, T.G.; Turek, R.J.; Keim, P. Hybrid populations selectively filter gene introgression between species. Evol. Int. J. Org. Evol. 2001, 55, 1325-1335. [CrossRef]

22. Lexer, C.; Fay, M.F.; Joseph, J.A.; Nica, M.-S.; Heinze, B. Barrier to gene flow between two ecologically divergent Populus species, P. alba (white poplar) and P. tremula (European aspen): The role of ecology and life history in gene introgression. Mol. Ecol. 2005, 14, 1045-1057. [CrossRef]

23. Suvanto, L.I.; Latva-Karjanmaa, T.B. Clone identification and clonal structure of the European aspen (Populus tremula). Mol. Ecol. 2005, 14, 2851-2860. [CrossRef]

24. Puschenreiter, M.; Türktaş, M.; Sommer, P.; Wieshammer, G.; Laaha, G.; Wenzel, W.W.; Hauser, M.-T. Differentiation of metallicolous and non-metallicolous Salix caprea populations based on phenotypic characteristics and nuclear microsatellite (SSR) markers. Plant Cell Environ. 2010, 33, 1641-1655. [CrossRef] [PubMed]

25. Anwar, G.M.; Helmey, R.K.; Mostafa, Y.M. Assesment of genetic diversityin garlic clones using SSR and ISSR markers. Egypt. J. Genet. Cytol. 2017, 45, 333-345. Available online: http://journal.esg.net.eg/index.php/ EJGC/article/view/233 (accessed on 22 July 2019). [CrossRef]

26. Dimsoski, P.; Toth, G.P. Development of DNA-based microsatellite marker technology for studies of genetic diversity in stressor impacted populations. Ecotoxicology 2001, 10, 229-232. [CrossRef]

27. Selkoe, K.A.; Toonen, R.J. Microsatellites for ecologists: A practical guide to using and evaluating microsatellite markers. Ecol. Lett. 2006, 9, 615-629. [CrossRef]

28. Vieira, M.L.C.; Santini, L.; Diniz, A.L.; Munhoz, C.D.F. Microsatellite markers: What they mean and why they are so useful. Genet. Mol. Biol. 2016, 39, 312-328. [CrossRef] [PubMed]

29. Wan, X.; Landhäusser, S.M.; Lieffers, V.J.; Zwiazek, J.J. Signals controlling root suckering and adventitious shoot formation in aspen (Populus tremuloides). Tree Physiol. 2006, 26, 681-687. [CrossRef]

30. Baryla, A.; Carrier, P.; Franck, F.; Coulomb, C.; Sahut, C.; Havaux, M. Leaf chlorosis in oilseed rape plants (Brassica napus) grown on cadmium-polluted soil: Causes and consequences for photosynthesis and growth. Planta 2001, 212, 696-709. [CrossRef] [PubMed]

31. Paunov, M.; Koleva, L.; Vassilev, A.; Vangronsveld, J.; Goltsev, V. Effects of Different Metals on Photosynthesis: Cadmium and Zinc Affect Chlorophyll Fluorescence in Durum Wheat. Int. J. Mol. Sci. 2018, 19, 787. [CrossRef]

32. Ondrasek, G.; Rengel, Z.; Romic, D. Humic acids decrease uptake and distribution of trace metals, but not the growth of radish exposed to cadmium toxicity. Ecotoxicol. Environ. Saf. 2018, 151, 55-61. [CrossRef]

33. Zhan, Y.-H.; Zhang, C.; Zheng, Q.-X.; Huang, Z.-A.; Yu, C.-L. Cadmium stress inhibits the growth of primary roots by interfering auxin homeostasis in Sorghum bicolor seedlings. J. Plant Biol. 2017, 60, 593-603. [CrossRef]

34. Schützendübel, A.; Nikolova, P.; Rudolf, C.; Polle, A. Cadmium and H2O2-induced oxidative stress in Populus $\times$ canescens roots. Plant Physiol. Biochem. 2002, 40, 577-584. [CrossRef]

35. Jiang, H.; Yang, J.; Zhang, J. Effects of external phosphorus on the cell ultrastructure and the chlorophyll content of maize under cadmium and zinc stress. Environ. Pollut. 2007, 147, 750-756. [CrossRef]

36. Kapoor, D.; Kaur, S.; Bhardwaj, R. Physiological and Biochemical Changes inBrassica junceaPlants under Cd-Induced Stress. BioMed Res. Int. 2014, 2014, 1-13. [CrossRef]

37. Dotaniya, M.L.; Meena, V.D.; Basak, B.B.; Meena, R.S. Potassium Uptake by Crops as Well as Microorganisms. In Potassium Solubilizing Microorganisms for Sustainable Agriculture; Springer: New Delhi, India, 2016; pp. 267-280.

38. Sadeghipour, O. Enhancing Cadmium Tolerance in Common Bean Plants by Potassium Application. Philipp. Agric. Sci. 2018, 101, 167-175.

39. Liu, S.; Yang, R.; Tripathi, D.K.; Li, X.; Jiang, M.; Lv, B.; Ma, M.; Qibing, C. RETRACTED: Signalling cross-talk between nitric oxide and active oxygen in Trifolium repens L. plants responses to cadmium stress. Environ. Pollut. 2018, 239, 53-68. [CrossRef]

40. Zhang, G.; Fukami, M.; Sekimoto, H. Influence of cadmium on mineral concentrations and yield components in wheat genotypes differing in Cd tolerance at seedling stage. Field Crop. Res. 2002, 77, 93-98. [CrossRef]

41. Rivetta, A.; Negrini, N.; Cocucci, M. Involvement of Ca2+-calmodulin in Cd2+ toxicity during the early phases of radish (Raphanus sativus L.) seed germination. Plant Cell Environ. 1997, 20, 600-608. [CrossRef]

42. Tkalec, M.; Štefanić, P.P.; Cvjetko, P.; Šikić, S.; Pavlica, M.; Balen, B. The Effects of Cadmium-Zinc Interactions on Biochemical Responses in Tobacco Seedlings and Adult Plants. PLoS ONE 2014, 9, e87582. [CrossRef] 
43. Courbot, M.; Willems, G.; Motte, P.; Arvidsson, S.; Roosens, N.; Saumitou-Laprade, P.; Verbruggen, N. A Major Quantitative Trait Locus for Cadmium Tolerance in Arabidopsis halleri Colocalizes with HMA4, a Gene Encoding a Heavy Metal ATPase. Plant Physiol. 2007, 144, 1052-1065. [CrossRef]

44. Morel, M.; Crouzet, J.; Gravot, A.; Auroy, P.; Leonhardt, N.; Vavasseur, A.; Richaud, P. AtHMA3, a P1B-ATPase Allowing Cd/Zn/Co/Pb Vacuolar Storage in Arabidopsis. Plant Physiol. 2008, 149, 894-904. [CrossRef]

45. Di Lonardo, S.; Capuana, M.; Arnetoli, M.; Gabbrielli, R.; Gonnelli, C. Exploring the metal phytoremediation potential of three Populus alba L. clones using an in vitro screening. Environ. Sci. Pollut. Res. 2010, 18, 82-90. [CrossRef]

46. Nikolić, N.; Zoric, L.; Cvetković, I.; Pajević, S.; Borišev, M.; Orlović, S. Assessment of cadmium tolerance and phytoextraction ability in young Populus deltoides L. and Populus $\times$ euramericana plants through morpho-anatomical and physiological responses to growth in cadmium enriched soil. IForest-Biogeosci. For. 2017, 10, 635-644. [CrossRef]

47. Redovniković, I.R.; De Marco, A.; Proietti, C.; Hanousek, K.; Sedak, M.; Bilandžić, N.; JakovljeviĆ, T. Poplar response to cadmium and lead soil contamination. Ecotoxicol. Environ. Saf. 2017, 144, 482-489. [CrossRef] [PubMed]

48. Pietrini, F.; Zacchini, M.; Iori, V.; Pietrosanti, L.; Ferretti, M.; Massacci, A. Spatial distribution of cadmium in leaves and its impact on photosynthesis: Examples of different strategies in willow and poplar clones. Plant Biol. 2009, 12, 355-363. [CrossRef]

49. Vollenweider, P.; Cosio, C.; Günthardt-Goerg, M.S.; Keller, C. Localization and effects of cadmium in leaves of a cadmium-tolerant willow (Salix viminalis L.). Environ. Exp. Bot. 2006, 58, 25-40. [CrossRef]

50. Cosio, C.; DeSantis, L.; Frey, B.; Diallo, S.; Keller, C. Distribution of cadmium in leaves of Thlaspi caerulescens. J. Exp. Bot. 2005, 56, 765-775. [CrossRef]

51. Kumar, M.; Brar, A.; Yadav, M.; Chawade, A.; Vivekanand, V.; Pareek, N. Chitinases-Potential Candidates for Enhanced Plant Resistance towards Fungal Pathogens. Agriculture 2018, 8, 88. [CrossRef]

52. Cao, J.; Tan, X. Comprehensive Analysis of the Chitinase Family Genes in Tomato (Solanum lycopersicum). Plants 2019, 8, 52. [CrossRef] [PubMed]

53. Békésiová, B.; Hraška, Š.; Libantova, J.; Moravčíková, J.; Matušíková, I. Heavy-metal stress induced accumulation of chitinase isoforms in plants. Mol. Biol. Rep. 2007, 35, 579-588. [CrossRef]

54. Gálusová, T.; Rybanský, L'.; Mészáros, P.; Spieß, N.; Piršelová, B.; Kuna, R.; Libantova, J.; Moravčíková, J.; Hauptvogel, P.; Matušíková, I. Variable responses of soybean chitinases to arsenic and cadmium stress at the whole plant level. Plant Growth Regul. 2014, 76, 147-155. [CrossRef]

55. Breithaupt, C.; Kurzbauer, R.; Schaller, F.; Stintzi, A.; Schaller, A.; Huber, R.; Macheroux, P.; Clausen, T. Structural Basis of Substrate Specificity of Plant 12-Oxophytodienoate Reductases. J. Mol. Biol. 2009, 392, 1266-1277. [CrossRef]

56. Xiang, C.-B.; Oliver, D.J. Glutathione Metabolic Genes Coordinately Respond to Heavy Metals and Jasmonic Acid in Arabidopsis. Plant Cell 1998, 10, 1539. [CrossRef]

57. Maksymiec, W.; Krupa, Z. The effects of short-term exposition to Cd, excess $\mathrm{Cu}$ ions and jasmonate on oxidative stress appearing in Arabidopsis thaliana. Environ. Exp. Bot. 2006, 57, 187-194. [CrossRef]

58. Liu, T.; Liu, S.; Guan, H.; Ma, L.; Chen, Z.; Gu, H.; Qu, L. Transcriptional profiling of Arabidopsis seedlings in response to heavy metal lead (Pb). Environ. Exp. Bot. 2009, 67, 377-386. [CrossRef]

59. Velazhahan, R.; Datta, S.K.; Muthukrishnan, S. The PR-5 family: Thaumatin-like proteins. In PathogenesisRelated Proteins in Plants; CRC Press: Boca Raton, FL, USA, 1999; pp. 107-129. [CrossRef]

60. Sarowar, S.; Kim, Y.J.; Kim, E.N.; Kim, K.D.; Hwang, B.K.; Islam, R.; Shin, J.S. Overexpression of a pepper basic pathogenesis-related protein 1 gene in tobacco plants enhances resistance to heavy metal and pathogen stresses. Plant Cell Rep. 2005, 24, 216-224. [CrossRef]

61. Fecht-Christoffers, M.M.; Braun, H.-P.; Lemaitre-Guillier, C.; Vandorsselaer, A.; Horst, W.J. Effect of Manganese Toxicity on the Proteome of the Leaf Apoplast in Cowpea. Plant Physiol. 2003, 133, 1935-1946. [CrossRef]

62. Júnior, W.V.A.; Neto, C.F.D.O.; Filho, B.G.D.S.; Amarante, C.B.D.; Cruz, E.D.; Okumura, R.S.; Barbosa, A.V.C.; De Sousa, D.J.P.; Teixeira, J.; Botelho, A.D.S. Effect of cadmium on young plants of Virola surinamensis. AoB Plants 2019, 11, plz022. [CrossRef] [PubMed]

63. Lee, Y.; Donghwan, S.; Won-Yong, S.; InHwan, H.; Youngsook, L. Arabidopsis metallothioneins 2a and 3 enhance resistance to cadmium when expressed in Vicia faba guard cells. Plant Mol. Biol. 2004, 54, 805-815. [CrossRef] 
64. Gullner, G.; Komives, T.; Király, L.; Schröder, P. Glutathione S-Transferase Enzymes in Plant-Pathogen Interactions. Front. Plant Sci. 2018, 9, 1836. [CrossRef]

65. Khan, N.; Hu, C.-M.; Khan, W.A.; Hou, X. Genome-Wide Identification, Classification, and Expression Divergence of Glutathione-Transferase Family in Brassica rapa under Multiple Hormone Treatments. BioMed Res. Int. 2018, 2018, 1-19. [CrossRef]

66. Srivastava, D.; Verma, G.; Chauhan, A.S.; Pande, V.; Chakrabarty, D. Rice (Oryza sativa L.) tau class glutathione S-transferase (OsGSTU30) overexpression in Arabidopsis thaliana modulates a regulatory network leading to heavy metal and drought stress tolerance. Metallomics 2019, 11, 375-389. [CrossRef]

67. Yang, Q.; Liu, Y.-J.; Zeng, Q. Overexpression of three orthologous glutathione S-transferases from Populus increased salt and drought resistance in Arabidopsis. Biochem. Syst. Ecol. 2019, 83, 57-61. [CrossRef]

68. Li, L.; Hou, M.; Cao, L.; Xia, Y.; Shen, Z.; Hu, Z. Glutathione S-transferases modulate Cu tolerance in Oryza sativa. Environ. Exp. Bot. 2018, 155, 313-320. [CrossRef]

69. Du, J.; Ren, J.; Ye, X.; Hou, A.; Fu, W.; Mei, F. Genome-wide identification and expression analysis of the glutathione S-transferase (GST) family under different developmental tissues and abiotic stresses in Chinese cabbage (Brassica rapa ssp. pekinensis). PeerJ 2018. [CrossRef]

70. Lan, T.; Yang, Z.-L.; Yang, X.; Liu, Y.-J.; Wang, X.-R.; Zeng, Q. Extensive Functional Diversification of the Populus Glutathione S-Transferase Supergene Family. Plant Cell 2009, 21, 3749-3766. [CrossRef]

71. Kieffer, P.; Dommes, J.; Hoffmann, L.; Hausman, J.-F.; Renaut, J. Quantitative changes in protein expression of cadmium-exposed poplar plants. Proteomics 2008, 8, 2514-2530. [CrossRef] [PubMed]

72. Tognetti, V.B.; Van Aken, O.; Morreel, K.; Vandenbroucke, K.; Van De Cotte, B.; De Clercq, I.; Chiwocha, S.; Fenske, R.; Prinsen, E.; Boerjan, W.; et al. Perturbation of Indole-3-Butyric Acid Homeostasis by the UDP-Glucosyltransferase UGT74E2 Modulates Arabidopsis Architecture and Water Stress Tolerance. Plant Cell 2010, 22, 2660-2679. [CrossRef]

73. Hu, Y.F.; Zhou, G.; Na, X.F.; Yang, L.; Bin Nan, W.; Liu, X.; Zhang, Y.Q.; Li, J.L.; Bi, Y. Cadmium interferes with maintenance of auxin homeostasis in Arabidopsis seedlings. J. Plant Physiol. 2013, 170, 965-975. [CrossRef]

74. Murashige, T.; Skoog, F. A Revised Medium for Rapid Growth and Bio Assays with Tobacco Tissue Cultures. Physiol. Plant. 1962, 15, 473-497. [CrossRef]

75. Van Der Schoot, J.; Pospíšková, M.; Vosman, B.; Smulders, M.J.M. Development and characterization of microsatellite markers in black poplar (Populus nigra L.). Theor. Appl. Genet. 2000, 101, 317-322. [CrossRef]

76. Smulders, M.J.M.; Van Der Schoot, J.; Arens, P.; Vosman, B. Trinucleotide repeat microsatellite markers for black poplar (Populus nigra L.). Mol. Ecol. Notes 2001, 1, 188-190. [CrossRef]

77. Tuskan, G.A.; Gunter, L.E.; Yang, Z.K.; Yin, T.; Sewell, M.M.; DiFazio, S.P. Characterization of microsatellites revealed by genomic sequencing of Populus trichocarpa. Can. J. For. Res. 2004, 34, 85-93. [CrossRef]

78. Loo, M.V.; Joseph, J.A.; Heinze, B.; Fay, M.F.; Lexer, C. Clonality and spatial genetic structure in Populus $\times$ canescens and its sympatric backcross parent P. alba in a Central European hybrid zone. New Phytol. 2008, 177, 506-516.

79. Politov, D.V.; Belokon, M.M.; Belokon, Y.S.; Polyakova, T.A.; Shatokhina, A.V.; Mudrik, E.A.; Azarova, A.B.; Filippov, M.V.; Shestibratov, K.A. Application of Microsatellite Loci for Molecular Identification of Elite Genotypes, Analysis of Clonality, and Genetic Diversity in Aspen Populus tremula L. (Salicaceae). Int. J. Plant Genom. 2015, 2015, 1-11. [CrossRef]

80. Pokorna, E.; Cizkova, L.; Machova, P.; Cvrckova, H.; Burianek, V.; Komarkova, M. Characterization of genetic diversity of local population of grey poplar (Populus $\times$ canescens Aiton Sm.) using SSR marers and phenotypic evaluation. Rep. For. Res. 2018, 63, 281-289.

81. Guichoux, E.; Lagache, L.; Wagner, S.; Chaumeil, P.; Léger, P.; Lepais, O.; Lepoittevin, C.; Malausa, T.; Revardel, E.; Salin, F.; et al. Current trends in microsatellite genotyping. Mol. Ecol. Resour. 2011, 11, 591-611. [CrossRef]

82. Vandesompele, J.; De Preter, K.; Pattyn, F.; Poppe, B.; Van Roy, N.; De Paepe, A.; Speleman, F. Accurate normalization of real-time quantitative RT-PCR data by geometric averaging of multiple internal control genes. Genome Biol. 2002, 3. [CrossRef]

83. Brentner, L.B.; Mukherji, S.T.; Merchie, K.M.; Yoon, J.M.; Schnoor, J.L.; Van Aken, B. Expression of glutathione S-transferases in poplar trees (Populus trichocarpa) exposed to 2,4,6-trinitrotoluene (TNT). Chemosphere 2008, 73, 657-662. [CrossRef] 
84. Basa, B.; Solti, Á.; Sárvári, É.; Tamás, L. Housekeeping gene selection in poplar plants under Cd-stress: Comparative study for real-time PCR normalisation. Funct. Plant Biol. 2009, 36, 1079-1087. [CrossRef] [PubMed]

85. Kieffer, P.; Schröder, P.; Dommes, J.; Hoffmann, L.; Renaut, J.; Hausman, J.-F. Proteomic and enzymatic response of poplar to cadmium stress. J. Proteom. 2009, 72, 379-396. [CrossRef]

86. He, J.; Li, H.; Luo, J.; Ma, C.; Li, S.; Qu, L.; Gai, Y.; Jiang, X.; Janz, D.; Polle, A.; et al. A Transcriptomic Network Underlies Microstructural and Physiological Responses to Cadmium in Populus $\times$ canescens. Plant Physiol. 2013, 162, 424-439. [CrossRef] [PubMed]

87. Kohler, A.; Blaudez, D.; Chalot, M.; Martin, F. Cloning and expression of multiple metallothioneins from hybrid poplar. New Phytol. 2004, 164, 83-93. [CrossRef]

88. Gaudet, M.; Pietrini, F.; Beritognolo, I.; Iori, V.; Zacchini, M.; Massacci, A.; Mugnozza, G.S.; Sabatti, M. Intraspecific variation of physiological and molecular response to cadmium stress in Populus nigra $\mathrm{L}$. Tree Physiol. 2011, 31, 1309-1318. [CrossRef]

89. Sumanta, N.; Haque, C.; Nishika, J.; Suprakash, R. Spectrophotometric Analysis of Chlorophylls and Carotenoids from Commonly Grown Fern Species by Using Various Extracting Solvents. Res. J. Chem. Sci. 2014, 4, 63-69.

90. Hoagland, D.R.; Arnon, D.I. Growing Plants without Soil by the Water-Culture Method. Grow Plants Soil Water-Cult Method. 1938. Available online: https://www.cabdirect.org/cabdirect/abstract/19381900944 (accessed on 15 September 2020).

Publisher's Note: MDPI stays neutral with regard to jurisdictional claims in published maps and institutional affiliations.

(C) 2020 by the authors. Licensee MDPI, Basel, Switzerland. This article is an open access article distributed under the terms and conditions of the Creative Commons Attribution (CC BY) license (http://creativecommons.org/licenses/by/4.0/). 